Universidad

:

BIBLIOTECA

Document downloaded from the institutional repository of the University of Alcala: https://ebuah.uah.es/dspace/

This is a postprint version of the following published document:

Caballo, J. et al., 2011. Molecular nitrides with titanium and rare-earth metals. Inorganic chemistry, 50(14), pp.6798-6808.

Available at https://doi.org/10.1021/ic2008683

(c) 2011 American Chemical Society.
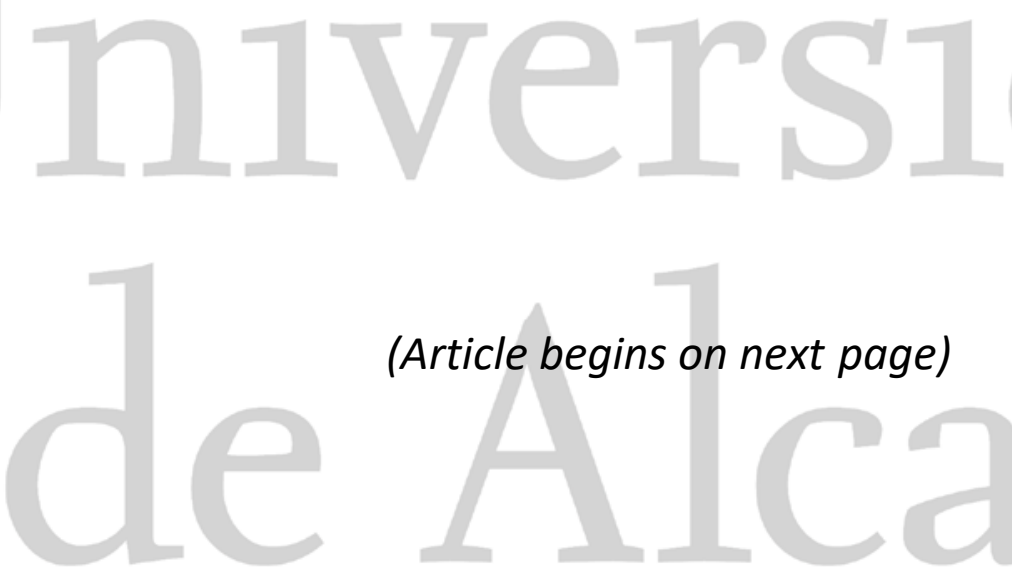

(Article begins on next page)

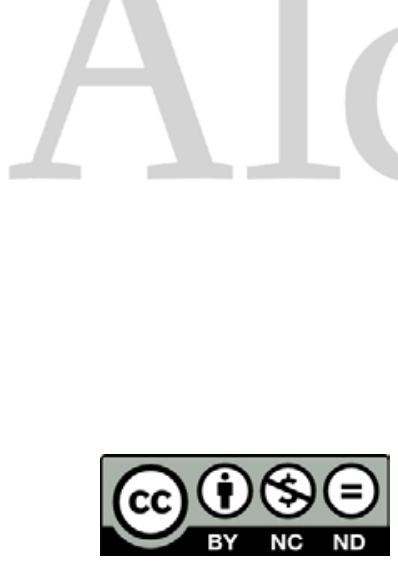

This work is licensed under a

Creative Commons Attribution-NonCommercial-NoDerivatives

4.0 International License. 


\section{Molecular Nitrides with Titanium and Rare-Earth Metals}

Jorge Caballo, María García-Castro, Avelino Martín, Miguel Mena, Adrián Pérez-Redondo, and Carlos Yélamos*

Departamento de Química Inorgánica, Universidad de Alcalá, 28871 Alcalá de HenaresMadrid (Spain). FAX: (+34) 91-8854683. E-mail: carlos.yelamos@uah.es

\section{Synopsis:}

A systematic synthetic route is disclosed for titanium-group 3/lanthanide metal complexes using the reaction of $\left[\left\{\mathrm{Ti}\left(\eta^{5}-\mathrm{C}_{5} \mathrm{Me}_{5}\right)(\mu-\mathrm{NH})\right\}_{3}\left(\mu_{3}-\mathrm{N}\right)\right]$ (1) and halide, triflate or amido derivatives of the rare-earth metals. The metalloligand $\mathbf{1}$ acts as a facially coordinating neutral six-electron donor in cube-type complexes or can be deprotonated to yield double-cube nitrido derivatives (see picture). Pyrolysis of the titanium-yttrium double-cube compound under $\mathrm{NH}_{3}$ produces a metal nitride material with a negligible carbon level.

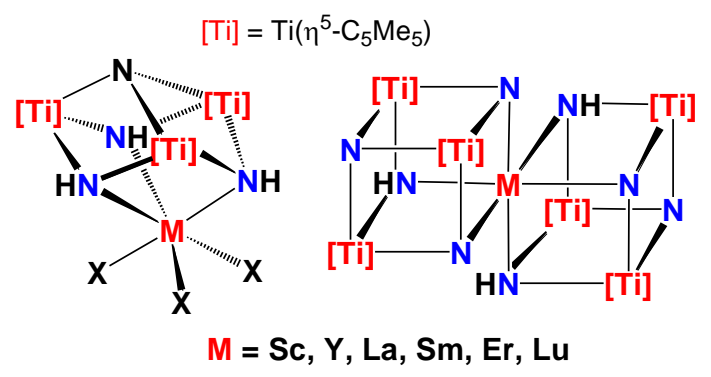




\section{Abstract:}

A series of titanium-group 3/lanthanide metal complexes have been prepared by reaction of $\left[\left\{\mathrm{Ti}\left(\eta^{5}-\mathrm{C}_{5} \mathrm{Me}_{5}\right)(\mu-\mathrm{NH})\right\}_{3}\left(\mu_{3}-\mathrm{N}\right)\right](\mathbf{1})$ with halide, triflate or amido derivatives of the rare-earth metals. Treatment of $\mathbf{1}$ with metal halide complexes $\left[\mathrm{MCl}_{3}(\text { thf })_{\mathrm{n}}\right]$ or metal trifluoromethanesulfonate derivatives $\left[\mathrm{M}\left(\mathrm{O}_{3} \mathrm{SCF}_{3}\right)_{3}\right]$ at room temperature affords the cubetype adducts $\left[\mathrm{X}_{3} \mathrm{M}\left\{\left(\mu_{3}-\mathrm{NH}\right)_{3} \mathrm{Ti}_{3}\left(\eta^{5}-\mathrm{C}_{5} \mathrm{Me}_{5}\right)_{3}\left(\mu_{3}-\mathrm{N}\right)\right\}\right](\mathrm{X}=\mathrm{Cl}, \mathrm{M}=\mathrm{Sc}(\mathbf{2}), \mathrm{Y}(\mathbf{3}), \mathrm{La}(\mathbf{4}), \mathrm{Sm}$ (5), $\operatorname{Er}(\mathbf{6}), \mathrm{Lu}(\mathbf{7}) ; \mathrm{X}=\mathrm{OTf}, \mathrm{M}=\mathrm{Y}(\mathbf{8}), \operatorname{Sm}(\mathbf{9}), \operatorname{Er}(\mathbf{1 0}))$. Treatment of yttrium (3) and lanthanum (4) halide complexes with three equivalents of lithium 2,6-dimethylphenoxido [LiOAr] produces the aryloxido complexes $\left[(\mathrm{ArO})_{3} \mathrm{M}\left\{\left(\mu_{3}-\mathrm{NH}\right)_{3} \mathrm{Ti}_{3}\left(\eta^{5}-\mathrm{C}_{5} \mathrm{Me}_{5}\right)_{3}\left(\mu_{3}-\mathrm{N}\right)\right\}\right](\mathrm{M}=$ Y (11), La (12)). Complex 1 reacts with 0.5 equiv of rare-earth bis(trimethylsilyl)amido derivatives $\left[\mathrm{M}\left\{\mathrm{N}\left(\mathrm{SiMe}_{3}\right)_{2}\right\}_{3}\right]$ in toluene at $85-180{ }^{\circ} \mathrm{C}$ to afford the corner-shared double-cube nitrido compounds $\left[\mathrm{M}\left(\mu_{3}-\mathrm{N}\right)_{3}\left(\mu_{3}-\mathrm{NH}\right)_{3}\left\{\mathrm{Ti}_{3}\left(\eta^{5}-\mathrm{C}_{5} \mathrm{Me}_{5}\right)_{3}\left(\mu_{3}-\mathrm{N}\right)\right\}_{2}\right](\mathrm{M}=\mathrm{Sc}(\mathbf{1 3}), \mathrm{Y}(\mathbf{1 4}), \mathrm{La}$ (15), $\mathrm{Sm}$ (16), Eu (17), $\mathrm{Er}$ (18), Lu (19)) via $\mathrm{NH}\left(\mathrm{SiMe}_{3}\right)_{2}$ elimination. A single-cube intermediate $\left[\left\{\left(\mathrm{Me}{ }_{3} \mathrm{Si}\right)_{2} \mathrm{~N}\right\} \operatorname{Sc}\left\{\left(\mu_{3}-\mathrm{N}\right)_{2}\left(\mu_{3}-\mathrm{NH}\right) \mathrm{Ti}_{3}\left(\eta^{5}-\mathrm{C}_{5} \mathrm{Me}_{5}\right)_{3}\left(\mu_{3}-\mathrm{N}\right)\right\}\right]$ (20) was obtained by the treatment of $\mathbf{1}$ with one equivalent of the scandium bis(trimethylsilyl)amido derivative $\left[\mathrm{Sc}\left\{\mathrm{N}\left(\mathrm{SiMe}_{3}\right)_{2}\right\}_{3}\right]$. The X-ray crystal structures of 2, 7, 11, 14, 15, and 19 have been determined. The thermal decomposition in the solid state of double-cube nitrido complexes 14, 15, and 18 has been investigated by TGA/DTA measurements, as well as by pyrolysis experiments at $1100{ }^{\circ} \mathrm{C}$ under different atmospheres $\left(\mathrm{Ar}, \mathrm{H}_{2} / \mathrm{N}_{2}, \mathrm{NH}_{3}\right)$ for the yttrium complex 14. 


\section{Introduction}

Polynuclear transition-metal nitrido complexes constitute a class of molecular cage compounds with fascinating structures and interesting bonding properties. ${ }^{1}$ While nitrido complexes of the mid transition-metals (groups 6, 7, and 8) in high oxidation state are usually mononuclear and feature terminal nitrido ligands, ${ }^{2}$ in early transition-metal (groups 4 and 5) systems there is a stronger tendency to form dimeric or oligomeric species with nitrido ligands bridging two or more metal centers. Structurally characterized examples include di--, 3,4 tri-,${ }^{5,6}$ tetra-,${ }^{7}$ penta-,${ }^{8}$ and hexanuclear ${ }^{9}$ complexes with nitrido moieties shared between the metal centers. In those examples, the presence of bulky ancillary ligands (e.g., cyclopentadienyl, alkoxido) at the metal centers is crucial to obtain discrete and soluble molecular compounds. Species with $\mu_{\mathrm{n}}$-nitrido groups are proposed as intermediates in dinitrogen fixation and activation,,$^{10,11,12}$ and new structural and electronic data on molecular systems may provide insights into those processes.

Interest in the development of polynuclear nitrido complexes is also due to their potential role as building blocks and precursors of metal nitride (MN) materials. ${ }^{13}$ Although the literature precedents are still scarce, Wolczanski and co-workers have demonstrated that the geometry of the nitrido tantalum precursor $\left[\left(t \mathrm{BuCH}_{2}\right)_{2} \mathrm{TaN}\right] 5 \cdot \mathrm{NH}_{3} \cdot 2 \mathrm{C}_{7} \mathrm{H}_{8}$ allows access to cubic $\mathrm{TaN}$ at $820^{\circ} \mathrm{C}$, instead of the hexagonal phase, which is more thermodynamically stable at that temperature. ${ }^{8 \mathrm{a}, 14}$ In this context, molecular heterometallic nitrido compounds with preformed $\mathrm{M}-\mathrm{N}-\mathrm{M}^{\prime}$ linkages are attractive candidates to serve as precursors of ternary metal nitrides, ${ }^{15}$ or homogeneous ceramic composites consisting of two or more binary nitrides. Thermal decomposition of heterobimetallic precursors with well-defined structures can offer a unique and facile approach for the preparation of materials with optimum distribution of both metals. The advantage of this method over the classical multicomponent approach has 
recently been demonstrated for the preparation of heterobimetallic oxide materials from organometallic cage precursors. ${ }^{16}$ A review of the literature shows several examples of the use of molecular or polymeric precursors in the synthesis of ternary metal nitrides or homogeneous nitride composites, ${ }^{13,17}$ but the search reveals also the lack of systematic strategies for the rational construction of aggregates with desired metal compositions.

As part of a project devoted to the development of polynuclear nitrido complexes, we have been investigating the rational synthesis of a family of heterometallic nitrido complexes by treatment of the trinuclear titanium imido-nitrido complex $\left[\left\{\mathrm{Ti}\left(\eta^{5}-\mathrm{C}_{5} \mathrm{Me}_{5}\right)(\mu-\mathrm{NH})\right\}_{3}\left(\mu_{3}-\right.\right.$ $\mathrm{N})]^{4,6}(\mathbf{1})$ with a variety of metal derivatives. Compound 1 shows an incomplete-cube [Ti( $\mu-$ $\left.\mathrm{NH})_{3}\left(\mu_{3}-\mathrm{N}\right)\right]$ core and is prone to incorporate metal fragments into the structure to give cubetype heterometallic complexes. The sterically demanding pentamethylcyclopentadienyl groups on the titanium atoms of $\mathbf{1}$ are crucial to confer solubility and stability to those polynuclear nitrido complexes, enabling to uncover a diverse spectrum of chemical structure and reactivity in this area. Our previous work has shown that $\mathbf{1}$ is capable of acting as a neutral chelate ligand through the basal $\mathrm{NH}$ groups towards transition ${ }^{18}$ and main-group ${ }^{19}$ metal derivatives. We have also recently reported the preliminary results on the coordination of $\mathbf{1}$ to yttrium and erbium halides. ${ }^{20}$ In those complexes, $\mathbf{1}$ acts as a facially coordinating ligand to the rare-earth centers and resembles other six-electron donors as the anionic tris(pyrazolyl)borates, ${ }^{21}$ the neutral analogous tris(pyrazolyl)methanes and tris(pyrazolyl)silanes, ${ }^{22,23}$ and cyclic triamines such as 1,4,7-triazacyclononanes ${ }^{23,24}$ and 1,3,5triazacyclohexanes. ${ }^{23 b, 25}$ Herein we report a systematic study on the coordination of the metalloligand 1 to group 3 and lanthanide metals, as well as preliminary experiments on the solid-state thermal decomposition of several molecular nitrides with titanium and rare-earth metals. 


\section{Experimental Section}

General Considerations. All manipulations were carried out under argon atmosphere using Schlenk line or glovebox techniques. Toluene and hexane were distilled from $\mathrm{Na} / \mathrm{K}$ alloy just before use. Tetrahydrofuran was distilled from purple solutions of sodium benzophenone just prior to use. NMR solvents were dried with $\mathrm{Na} / \mathrm{K}$ alloy $\left(\mathrm{C}_{6} \mathrm{D}_{6}\right)$ or calcium hydride $\left(\mathrm{CDCl}_{3}\right)$ and vacuum-distilled. Oven-dried glassware was repeatedly evacuated with a pumping system (ca. $1 \times 10^{-3}$ Torr) and subsequently filled with inert gas. Thermolyses in solution at high temperatures were carried out by heating flame-sealed NMR or Carius tubes in a Roth autoclave model III. Anhydrous group 3 and lanthanide metal halides $\left[\mathrm{MCl}_{3}\right]$ were purchased from Aldrich or Strem and used as received. The tetrahydrofuran adducts $\left[\mathrm{MCl}_{3}(\mathrm{thf})_{\mathrm{n}}\right]^{26}(\mathrm{M}=$ Sc, $\mathrm{Lu}, \mathrm{n}=3 ; \mathrm{M}=\mathrm{Y}, \mathrm{Sm}, \mathrm{Er}, \mathrm{n}=3.5 ; \mathrm{M}=\mathrm{La},{ }^{27} \mathrm{n}=1.5$ ) were prepared by heating under reflux a suspension of $\left[\mathrm{MCl}_{3}\right]$ in tetrahydrofuran. Metal tris(trifluoromethanesulfonate) reagents $\left[\mathrm{M}\left(\mathrm{O}_{3} \mathrm{SCF}_{3}\right)_{3}\right](\mathrm{M}=\mathrm{Y}, \mathrm{La}, \mathrm{Sm}, \mathrm{Er})$ were purchased from Aldrich, and heated at 180 ${ }^{\circ} \mathrm{C}$ under dynamic vacuum prior to use. Lithium 2,6-dimethylphenoxido [Li(OAr)] was prepared by reaction of 2,6-dimethylphenol with [LinBu] (Aldrich, 1.6 M in hexane). [\{Ti( $\eta^{5}$ $\left.\left.\left.\mathrm{C}_{5} \mathrm{Me}_{5}\right)(\mu-\mathrm{NH})\right\}_{3}\left(\mu_{3}-\mathrm{N}\right)\right](\mathbf{1}),{ }^{4,6}\left[\mathrm{Y}\left(\mathrm{CH}_{2} \mathrm{SiMe}_{3}\right)_{3}(\mathrm{thf})_{3}\right],{ }^{28}$ and $\left[\mathrm{M}\left\{\mathrm{N}\left(\mathrm{SiMe}_{3}\right)_{2}\right\}_{3}\right]\left(\mathrm{M}=\mathrm{Sc},{ }^{29} \mathrm{Y}\right.$, $\mathrm{La}, \mathrm{Sm}, \mathrm{Eu}, \mathrm{Er}, \mathrm{Lu})^{30}$ were prepared according to published procedures. The syntheses and characterization of complexes $\mathbf{3}$ and $\mathbf{6}$ have been reported previously. ${ }^{20}$

Samples for infrared spectroscopy were prepared as $\mathrm{KBr}$ pellets. ${ }^{1} \mathrm{H},{ }^{13} \mathrm{C}\left\{{ }^{1} \mathrm{H}\right\}$ and ${ }^{19} \mathrm{~F}$ NMR spectra were recorded on a Varian Unity-300 and/or Mercury-300 spectrometers. Chemical shifts $\left(\delta\right.$, ppm) in the ${ }^{1} \mathrm{H}$ and ${ }^{13} \mathrm{C}\left\{{ }^{1} \mathrm{H}\right\}$ NMR spectra are given relative to residual protons or to carbon of the solvent. Chemical shifts $(\delta, \mathrm{ppm})$ in the ${ }^{19} \mathrm{~F}$ NMR spectra are given relative to $\mathrm{CFCl}_{3}$ as external reference. Microanalyses $(\mathrm{C}, \mathrm{H}, \mathrm{N}, \mathrm{S}, \mathrm{O})$ were performed in a Leco CHNSO-932 microanalyzer. Simultaneous DTA/TG analysis were conducted on a SDT 
Q600 TA instrument coupled with quadrupole mass spectrometer system (THERMOSTAR GSD300 T3) at the Instituto de Ciencias de Materiales de Madrid ICMM-CSIC. Samples were heated between 25 and $1000^{\circ} \mathrm{C}$ using argon as the flow gas (200 sccm) with a heating rate of $10^{\circ} \mathrm{C} / \mathrm{min}$ (sample weights $\approx 10 \mathrm{mg}$ ). SEM/EDX results were obtained on a Hitachi TM-1000 instrument with SwiftED-TM. Powder X-ray diffraction (PXRD) analyses were performed on a Bruker Model D8 Advance diffractometer using $\mathrm{Cu}$ K $\alpha$ radiation $(\lambda=1.5418$ $\AA)$.

Synthesis of $\left[\mathrm{Cl}_{3} \mathrm{Sc}\left\{\left(\mu_{3}-\mathrm{NH}\right)_{3} \mathbf{T i}_{3}\left(\eta^{5}-\mathrm{C}_{5} \mathbf{M e}_{5}\right)_{3}\left(\mu_{3}-\mathrm{N}\right)\right\}\right]$ (2). A $100 \mathrm{~mL}$ Schlenk flask was charged with $1(0.30 \mathrm{~g}, 0.49 \mathrm{mmol}),\left[\mathrm{ScCl}_{3}(\mathrm{thf})_{3}\right](0.18 \mathrm{~g}, 0.49 \mathrm{mmol})$, toluene $(20 \mathrm{~mL})$ and THF ( $5 \mathrm{~mL})$. The reaction mixture was stirred at room temperature for $24 \mathrm{~h}$ to give an orange solid and a brown solution. The solid was isolated by filtration onto a glass frit and vacuumdried to afford 2 as an orange powder $(0.26 \mathrm{~g}, 70 \%)$. IR $\left(\mathrm{KBr}, \mathrm{cm}^{-1}\right): \tilde{v} 3331$ (s), 2912 (s), 1487 (w), 1426 (m), 1380 (s), 1067 (w), 1024 (w), 730 (vs), 708 (vs), 664 (s), 643 (vs), 619 (s), $535(\mathrm{w}), 476(\mathrm{w}), 436(\mathrm{w}) .{ }^{1} \mathrm{H}$ NMR $\left(\mathrm{CDCl}_{3}, 20{ }^{\circ} \mathrm{C}\right): \delta 12.31$ (s br., 3H; NH), 2.17 (s, 45H; $\left.\mathrm{C}_{5} \mathrm{Me}_{5}\right) .{ }^{13} \mathrm{C}\left\{{ }^{1} \mathrm{H}\right\} \mathrm{NMR}\left(\mathrm{CDCl}_{3}, 20{ }^{\circ} \mathrm{C}\right): \delta 125.0\left(C_{5} \mathrm{Me}_{5}\right), 12.6\left(\mathrm{C}_{5} M e_{5}\right)$. Anal. Calcd for $\mathrm{C}_{30} \mathrm{H}_{48} \mathrm{Cl}_{3} \mathrm{~N}_{4} \mathrm{ScTi}_{3}\left(M_{\mathrm{w}}=759.65\right)$ : C 47.43, H 6.37, N 7.38. Found: C 47.21, H 6.00, N 6.97. Synthesis of $\left[\mathrm{Cl}_{3} \mathrm{La}\left\{\left(\mu_{3}-\mathrm{NH}\right)_{3} \mathrm{Ti}_{3}\left(\eta^{5}-\mathrm{C}_{5} \mathrm{Me}_{5}\right)_{3}\left(\mu_{3}-\mathrm{N}\right)\right\}\right]$ (4). In a fashion similar to the preparation of $\mathbf{2}$, the treatment of $1(0.50 \mathrm{~g}, 0.82 \mathrm{mmol})$ with $\left.\left[\mathrm{LaCl}_{3}(\mathrm{thf})\right)_{1.5}\right](0.28 \mathrm{~g}, 0.78$ $\mathrm{mmol})$ in toluene $(20 \mathrm{~mL})$ and THF $(5 \mathrm{~mL})$ afforded 4 as a yellow powder $(0.52 \mathrm{~g}, 78 \%)$. IR $\left(\mathrm{KBr}, \mathrm{cm}^{-1}\right): \tilde{v} 3310$ (s), 2909 (s), 2859 (m), 1489 (m), 1427 (s), 1378 (s), 1066 (w), 1025 (m), 758 (s), 695 (vs), 663 (vs), 532 (w), 475 (m), 431 (w). ${ }^{1} \mathrm{H}$ NMR $\left(\mathrm{CDCl}_{3}, 20{ }^{\circ} \mathrm{C}\right): \delta 13.37$ (s br., 3H; NH), 2.17 (s, 45H; $\left.\mathrm{C}_{5} \mathrm{Me}_{5}\right) .{ }^{13} \mathrm{C}\left\{{ }^{1} \mathrm{H}\right\} \mathrm{NMR}\left(\mathrm{CDCl}_{3}, 20{ }^{\circ} \mathrm{C}\right): \delta 123.7\left(C_{5} \mathrm{Me}_{5}\right), 12.7$ $\left(\mathrm{C}_{5} M e_{5}\right)$. Anal. Calcd for $\mathrm{C}_{30} \mathrm{H}_{48} \mathrm{Cl}_{3} \mathrm{LaN}_{4} \mathrm{Ti}_{3}\left(M_{\mathrm{w}}=853.61\right)$ : C 42.21, H 5.67, N 6.56. Found: C 41.82, H 5.30, N 6.36. 
Synthesis of $\left[\mathrm{Cl}_{3} \mathrm{Sm}\left\{\left(\mu_{3}-\mathrm{NH}\right)_{3} \mathrm{Ti}_{3}\left(\eta^{5}-\mathrm{C}_{5} \mathrm{Me}_{5}\right)_{3}\left(\mu_{3}-\mathrm{N}\right)\right\}\right]$ (5). In a fashion similar to the preparation of 2, the treatment of $1(0.30 \mathrm{~g}, 0.49 \mathrm{mmol})$ with $\left[\mathrm{SmCl}_{3}(\mathrm{thf})_{3.5}\right](0.25 \mathrm{~g}, 0.49$ mmol) in toluene $(20 \mathrm{~mL})$ and THF $(5 \mathrm{~mL})$ at room temperature for $24 \mathrm{~h}$ gave 5 as a yellow powder (0.35 g, 83\%). IR (KBr, cm $\left.{ }^{-1}\right): \tilde{v} 3312$ (s), 2909 (s), 1488 (m), 1427 (s), 1377 (s), 1066 (w), 1023 (m), 861 (w), 701 (vs), 656 (vs), 532 (w), 475 (m), 431 (w). ${ }^{1} \mathrm{H}$ NMR $\left(\mathrm{CDCl}_{3}, 20\right.$ $\left.{ }^{\circ} \mathrm{C}\right): \delta 13.55$ (s br., $\left.3 \mathrm{H} ; \mathrm{NH}\right), 1.99\left(\mathrm{~s}, 45 \mathrm{H} ; \mathrm{C}_{5} \mathrm{Me}_{5}\right) .{ }^{13} \mathrm{C}\left\{{ }^{1} \mathrm{H}\right\}$ NMR $\left(\mathrm{CDCl}_{3}, 20{ }^{\circ} \mathrm{C}\right): \delta 123.4$ $\left(C_{5} \mathrm{Me}_{5}\right), 12.3\left(\mathrm{C}_{5} M e_{5}\right)$. Anal. Calcd for $\mathrm{C}_{30} \mathrm{H}_{48} \mathrm{Cl}_{3} \mathrm{~N}_{4} \mathrm{SmTi}_{3}\left(M_{\mathrm{w}}=865.06\right)$ : C 41.65, H 5.59, N 6.48. Found: C 41.43, H 5.69, N 6.25.

Synthesis of $\left[\mathrm{Cl}_{3} \mathrm{Lu}\left\{\left(\boldsymbol{\mu}_{3}-\mathrm{NH}\right)_{3} \mathrm{Ti}_{3}\left(\eta^{5}-\mathrm{C}_{5} \mathrm{Me}_{5}\right)_{3}\left(\boldsymbol{\mu}_{3}-\mathrm{N}\right)\right\}\right]$ (7). In a fashion similar to the preparation of $\mathbf{2}$, the treatment of $\mathbf{1}(0.20 \mathrm{~g}, 0.33 \mathrm{mmol})$ with $\left[\mathrm{LuCl}_{3}(\mathrm{thf})_{3}\right](0.17 \mathrm{~g}, 0.33$ $\mathrm{mmol})$ in toluene $(20 \mathrm{~mL})$ and $\mathrm{THF}(5 \mathrm{~mL})$ at room temperature for $24 \mathrm{~h}$ afforded 7 as a yellow powder $(0.16 \mathrm{~g}, 55 \%)$. IR $\left(\mathrm{KBr}, \mathrm{cm}^{-1}\right): \tilde{v} 3329(\mathrm{~s}), 2912(\mathrm{~s}), 2859(\mathrm{~m}), 1485(\mathrm{~m}), 1425$ (s), 1380 (s), 1066 (w), 1024 (w), 775 (s), 736 (vs), 701 (vs), 643 (vs), 620 (vs), 535 (m), 477 (m), $436(\mathrm{w}), 407(\mathrm{w}) .{ }^{1} \mathrm{H} \mathrm{NMR}\left(\mathrm{CDCl}_{3}, 20^{\circ} \mathrm{C}\right): \delta 12.50$ (s br., 3H; NH), $2.17(\mathrm{~s}, 45 \mathrm{H}$; $\left.\mathrm{C}_{5} \mathrm{Me}_{5}\right) .{ }^{13} \mathrm{C}\left\{{ }^{1} \mathrm{H}\right\}$ NMR $\left(\mathrm{CDCl}_{3}, 20{ }^{\circ} \mathrm{C}\right): \delta 124.4\left(C_{5} \mathrm{Me}_{5}\right), 12.3\left(\mathrm{C}_{5} M e_{5}\right)$. Anal. Calcd for $\mathrm{C}_{30} \mathrm{H}_{48} \mathrm{Cl}_{3} \mathrm{LuN}_{4} \mathrm{Ti}_{3}\left(M_{\mathrm{w}}=889.66\right): \mathrm{C} 40.50, \mathrm{H}$ 5.44, N 6.30. Found: C 40.52, H 5.25, N 6.31.

Synthesis of $\left[\left(\mathrm{CF}_{3} \mathrm{SO}_{2} \mathrm{O}\right)_{3} \mathrm{Y}\left\{\left(\mu_{3}-\mathrm{NH}\right)_{3} \mathrm{Ti}_{3}\left(\eta^{5}-\mathrm{C}_{5} \mathrm{Me}\right)_{3}\left(\mu_{3}-\mathrm{N}\right)\right\}\right]$ (8). A $100 \mathrm{~mL}$ Schlenk flask was charged with $\left.1(0.30 \mathrm{~g}, 0.49 \mathrm{mmol}),\left[\mathrm{Y}_{(} \mathrm{O}_{3} \mathrm{SCF}_{3}\right)_{3}\right](0.24 \mathrm{~g}, 0.44 \mathrm{mmol})$, and toluene (30 $\mathrm{mL}$ ). The reaction mixture was stirred at room temperature for 2 days. The brown suspension was filtered through a coarse glass frit, and the resultant orange solid in the frit was vacuumdried and characterized as $8(0.36 \mathrm{~g}, 72 \%)$. IR $\left(\mathrm{KBr}, \mathrm{cm}^{-1}\right): \tilde{v} 3329(\mathrm{w}), 3294(\mathrm{w}), 2920(\mathrm{w})$, 1429 (w), 1383 (m), 1338 (vs), 1240 (vs), 1196 (vs), 1036 (vs), 1014 (s), 763 (m), 635 (vs), $512(\mathrm{~m}), 477$ (w). ${ }^{1} \mathrm{H}$ NMR $\left(\mathrm{CDCl}_{3}, 20{ }^{\circ} \mathrm{C}\right.$ ): $\delta 13.16$ (s br., 3H; NH), 2.18 (s, 45H; $\mathrm{C}_{5} \mathrm{Me}_{5}$ ). ${ }^{13} \mathrm{C}\left\{{ }^{1} \mathrm{H}\right\} \mathrm{NMR}\left(\mathrm{CDCl}_{3}, 20{ }^{\circ} \mathrm{C}\right): \delta 124.0\left(C_{5} \mathrm{Me}_{5}\right), 12.1\left(\mathrm{C}_{5} M e_{5}\right) .{ }^{19} \mathrm{~F} \mathrm{NMR}\left(\mathrm{CDCl}_{3}, 20{ }^{\circ} \mathrm{C}\right): \delta-$ 
77.9. Anal. Calcd for $\mathrm{C}_{33} \mathrm{H}_{48} \mathrm{~F}_{9} \mathrm{~N}_{4} \mathrm{O}_{9} \mathrm{~S}_{3} \mathrm{Ti}_{3} \mathrm{Y}\left(M_{\mathrm{w}}=1144.45\right)$ : C $34.63, \mathrm{H} 4.23, \mathrm{~N} 4.90, \mathrm{~S} 8.41$. Found: C 34.85, H 4.72, N 4.85, S 7.95.

Synthesis of $\left[\left(\mathrm{CF}_{3} \mathrm{SO}_{2} \mathrm{O}\right)_{3} \mathrm{Sm}\left\{\left(\mu_{3}-\mathrm{NH}\right)_{3} \mathrm{Ti}_{3}\left(\eta^{5}-\mathrm{C}_{5} \mathrm{Me}_{5}\right)_{3}\left(\mu_{3}-\mathrm{N}\right)\right\}\right]$ (9). In a fashion similar to the preparation of $\mathbf{8}$, the treatment of $\mathbf{1}(0.30 \mathrm{~g}, 0.49 \mathrm{mmol})$ with $\left[\mathrm{Sm}\left(\mathrm{O}_{3} \mathrm{SCF}_{3}\right)_{3}\right](0.28 \mathrm{~g}, 0.47$ mmol) in toluene $(30 \mathrm{~mL})$ at $70{ }^{\circ} \mathrm{C}$ for 2 days afforded 9 as an orange solid $(0.44 \mathrm{~g}, 77 \%)$. IR $\left(\mathrm{KBr}, \mathrm{cm}^{-1}\right): \tilde{v} 3325(\mathrm{w}), 3289(\mathrm{w}), 2920(\mathrm{w}), 1489(\mathrm{w}), 1429(\mathrm{w}), 1383(\mathrm{w}), 1337$ (s), 1237 (vs), 1195 (vs), 1030 (vs), 1010 (vs), 758 (s), 635 (vs), 594 (w), 536 (w), 512 (s), 476 (m), 440 (m). ${ }^{1} \mathrm{H}$ NMR $\left(\mathrm{CDCl}_{3}, 20{ }^{\circ} \mathrm{C}\right): \delta 13.87$ (s br., 3H; NH), $2.01\left(\mathrm{~s}, 45 \mathrm{H} ; \mathrm{C}_{5} \mathrm{Me}_{5}\right) .{ }^{13} \mathrm{C}\left\{{ }^{1} \mathrm{H}\right\}$ NMR $\left(\mathrm{CDCl}_{3}, 20{ }^{\circ} \mathrm{C}\right): \delta 125.3\left(C_{5} \mathrm{Me}_{5}\right), 12.0\left(\mathrm{C}_{5} \mathrm{Me}_{5}\right),{ }^{19} \mathrm{~F} \mathrm{NMR}\left(\mathrm{CDCl}_{3}, 20{ }^{\circ} \mathrm{C}\right): \delta$-77.5. Anal. Calcd for $\mathrm{C}_{33} \mathrm{H}_{48} \mathrm{~F}_{9} \mathrm{~N}_{4} \mathrm{O}_{9} \mathrm{~S}_{3} \mathrm{SmTi}_{3}\left(M_{\mathrm{w}}=1205.90\right)$ : C 32.87, H 4.01, N 4.65, S 7.98. Found: C 31.02, H 3.93, N 4.40, S 7.52.

Synthesis of $\left[\left(\mathrm{CF}_{3} \mathrm{SO}_{2} \mathrm{O}\right)_{3} \operatorname{Er}\left\{\left(\mu_{3}-\mathrm{NH}\right)_{3} \mathrm{Ti}_{3}\left(\eta^{5}-\mathrm{C}_{5} \mathrm{Me}_{5}\right)_{3}\left(\mu_{3}-\mathrm{N}\right)\right\}\right]$ (10). In a fashion similar to the preparation of $\mathbf{8}$, the treatment of $\mathbf{1}(0.30 \mathrm{~g}, 0.49 \mathrm{mmol})$ with $\left[\mathrm{Er}\left(\mathrm{O}_{3} \mathrm{SCF}_{3}\right)_{3}\right](0.29 \mathrm{~g}, 0.47$ $\mathrm{mmol})$ in toluene $(30 \mathrm{~mL})$ at room temperature for 2 days afforded $\mathbf{1 0}$ as an orange solid (0.46 g, 81\%). IR (KBr, cm $\left.{ }^{-1}\right): \tilde{v} 3329(\mathrm{w}), 3294(\mathrm{w}), 2920(\mathrm{w}), 1489(\mathrm{w}), 1429(\mathrm{w}), 1383(\mathrm{~m}), 1339$ (vs), 1241 (vs), 1196 (vs), 1036 (vs), 1013 (s), 763 (m), 635 (vs), 596 (w), 537 (w), 512 (m), 477 (w), 441 (w), 410 (w). Anal. Calcd for $\mathrm{C}_{33} \mathrm{H}_{48} \mathrm{ErF}_{9} \mathrm{~N}_{4} \mathrm{O}_{9} \mathrm{~S}_{3} \mathrm{Ti}_{3}\left(M_{\mathrm{w}}=1222.80\right)$ : C 32.41, H 3.96, N 4.58, S 7.87. Found: C 32.21, H 4.14, N 4.34, S 8.29.

Synthesis of $\left[(\mathbf{A r O})_{3} \mathbf{Y}\left\{\left(\mu_{3}-\mathbf{N H}\right)_{3} \mathbf{T i}_{3}\left(\eta^{5}-\mathrm{C}_{5} \mathbf{M e}_{5}\right)_{3}\left(\mu_{3}-\mathrm{N}\right)\right\}\right]$ (11). A $100 \mathrm{~mL}$ Schlenk flask was charged with 3 ( $0.30 \mathrm{~g}, 0.37 \mathrm{mmol})$, lithium 2,6-dimethylphenoxido (0.14 g, $1.12 \mathrm{mmol})$, and toluene $(50 \mathrm{~mL})$. The reaction mixture was stirred at ambient temperature for $24 \mathrm{~h}$ to give an orange solution and a white fine powder. After filtration, the volatile components of the solution were removed under reduced pressure to afford $\mathbf{1 1}$ as a yellow solid $(0.37 \mathrm{~g}, 95 \%)$. IR (KBr, cm $\left.{ }^{-1}\right): \tilde{v} 3347$ (s), 2944 (s), 2911 (s), 2856 (s), 1592 (s), 1468 (vs), 1427 (vs), 1377 
(s), 1299 (vs), 1279 (vs), 1240 (s), 1092 (s), 1025 (w), 976 (w), 917 (w), 859 (s), 799 (m), 746 (vs), 703 (s), 676 (vs), 656 (vs), 562 (w), 530 (s), 477 (m), 433 (w). ${ }^{1} \mathrm{H}$ NMR $\left(\mathrm{CDCl}_{3}, 20{ }^{\circ} \mathrm{C}\right)$ : $\delta 13.33(\mathrm{~s}$ br., $3 \mathrm{H} ; \mathrm{NH}), 6.76\left(\mathrm{~d},{ }^{3} J_{\mathrm{HH}}=7.5 \mathrm{~Hz}, 6 \mathrm{H} ; \mathrm{OC}_{6} H_{2} \mathrm{HMe}_{2}\right), 6.36\left(\mathrm{t},{ }^{3} J_{\mathrm{HH}}=7.5 \mathrm{~Hz}, 3 \mathrm{H}\right.$; $\mathrm{OC}_{6} \mathrm{H}_{2} H \mathrm{Me}_{2}$ ), 2.08 (s, 45H; $\left.\mathrm{C}_{5} \mathrm{Me}_{5}\right), 2.00$ (s, 18H; $\left.\mathrm{OC}_{6} \mathrm{H}_{2} \mathrm{HMe} 2\right) .{ }^{13} \mathrm{C}\left\{{ }^{1} \mathrm{H}\right\} \mathrm{NMR}\left(\mathrm{CDCl}_{3}, 20\right.$ $\left.{ }^{\circ} \mathrm{C}\right): \delta 161.7\left(\mathrm{~d},{ }^{2} J_{\mathrm{CY}}=4.9 \mathrm{~Hz} ;\right.$ ipso- $\left.\mathrm{OC}_{6} \mathrm{H}_{2} \mathrm{HMe}_{2}\right), 127.4\left(m-\mathrm{OC}_{6} \mathrm{H}_{2} \mathrm{HMe}_{2}\right), 125.6(o-$ $\left.\mathrm{OC}_{6} \mathrm{H}_{2} \mathrm{HMe}_{2}\right), 122.5$ ( $\left.C_{5} \mathrm{Me}_{5}\right), 114.4$ (p-OC $\left.{ }_{6} \mathrm{H}_{2} \mathrm{HMe}_{2}\right), 18.7\left(\mathrm{OC}_{6} \mathrm{H}_{2} \mathrm{H} M e_{2}\right), 11.9\left(\mathrm{C}_{5} M e_{5}\right)$. Anal. Calcd for $\mathrm{C}_{54} \mathrm{H}_{75} \mathrm{~N}_{4} \mathrm{O}_{3} \mathrm{Ti}_{3} \mathrm{Y}\left(M_{\mathrm{w}}=1060.71\right)$ : C 61.15, H 7.13, N 5.28. Found: C 61.13, H 6.81, N 5.07.

Synthesis of $\left[(\mathrm{ArO})_{3} \mathrm{La}\left\{\left(\mu_{3}-\mathrm{NH}\right)_{3} \mathrm{Ti}_{3}\left(\eta^{5}-\mathrm{C}_{5} \mathrm{Me}_{5}\right)_{3}\left(\mu_{3}-\mathrm{N}\right)\right\}\right]$ (12). In a fashion similar to the preparation of 11, the treatment of $\mathbf{4}(0.30 \mathrm{~g}, 0.35 \mathrm{mmol})$ with lithium 2,6-dimethylphenoxido $(0.14 \mathrm{~g}, 1.05 \mathrm{mmol})$ in toluene $(50 \mathrm{~mL})$ at room temperature for $24 \mathrm{~h}$ afforded $\mathbf{1 2}$ as a yellow solid (0.32 g, 82\%). IR (KBr, cm $\left.{ }^{-1}\right): \tilde{v} 3336$ (m), 2910 (s), 1591 (s), 1465 (vs), 1425 (vs), 1377 (m), 1293 (vs), 1274 (vs), 1237 (vs), 1090 (m), 1025 (w), 974 (w), 915 (w), 851 (m), 746 (vs), 697 (m), 667 (vs), 654 (vs), $526(\mathrm{~m}), 476(\mathrm{~m}), 432(\mathrm{w}) .{ }^{1} \mathrm{H} \mathrm{NMR}\left(\mathrm{CDCl}_{3}, 20{ }^{\circ} \mathrm{C}\right): \delta 13.59$ (s br., $3 \mathrm{H} ; \mathrm{NH}), 6.80\left(\mathrm{~d},{ }^{3} J_{\mathrm{HH}}=7.5 \mathrm{~Hz}, 6 \mathrm{H} ; \mathrm{OC}_{6} H_{2} \mathrm{HMe}_{2}\right), 6.37\left(\mathrm{t},{ }^{3} J_{\mathrm{HH}}=7.5 \mathrm{~Hz}, 3 \mathrm{H}\right.$; $\mathrm{OC}_{6} \mathrm{H}_{2} H \mathrm{Me}_{2}$ ), 2.07 (s, 45H; $\left.\mathrm{C}_{5} \mathrm{Me}_{5}\right), 2.04$ (s, 18H; $\left.\mathrm{OC}_{6} \mathrm{H}_{2} \mathrm{HMe} 2\right) .{ }^{13} \mathrm{C}\left\{{ }^{1} \mathrm{H}\right\} \mathrm{NMR}\left(\mathrm{CDCl}_{3}, 20\right.$ $\left.{ }^{\circ} \mathrm{C}\right): \quad \delta 163.1 \quad\left(\right.$ ipso- $\left.\mathrm{OC}_{6} \mathrm{H}_{2} \mathrm{HMe}_{2}\right), \quad 127.3 \quad\left(m-C_{6} \mathrm{H}_{2} \mathrm{HMe}_{2}\right), \quad 125.1 \quad\left(o-\mathrm{OC}_{6} \mathrm{H}_{2} \mathrm{HMe}_{2}\right), \quad 122.0$ $\left(C_{5} \mathrm{Me}_{5}\right), 114.3\left(p-\mathrm{OC}_{6} \mathrm{H}_{2} \mathrm{HMe}_{2}\right), 18.5\left(\mathrm{OC}_{6} \mathrm{H}_{2} \mathrm{H} M e_{2}\right), 11.8 \quad\left(\mathrm{C}_{5} M e_{5}\right)$. Anal. Calcd for $\mathrm{C}_{54} \mathrm{H}_{75} \mathrm{LaN}_{4} \mathrm{O}_{3} \mathrm{Ti}_{3}\left(M_{\mathrm{w}}=1110.71\right)$ : C 58.39, H 6.81, N 5.04. Found: C 58.16, H 6.84, N 4.75.

Synthesis of $\left[\mathbf{S c}\left(\mu_{3}-\mathbf{N}\right)_{3}\left(\mu_{3}-\mathbf{N H}\right)_{3}\left\{\mathbf{T i}_{3}\left(\eta^{5}-\mathbf{C}_{5} \mathbf{M e}_{5}\right)_{3}\left(\mu_{3}-\mathbf{N}\right)\right\}_{2}\right]$ (13). A $100 \mathrm{~mL}$ Carius tube was charged with $1(0.30 \mathrm{~g}, 0.49 \mathrm{mmol}),\left[\mathrm{Sc}\left\{\mathrm{N}\left(\mathrm{SiMe}_{3}\right)_{2}\right\}_{3}\right](0.13 \mathrm{~g}, 0.25 \mathrm{mmol})$, and toluene (15 $\mathrm{mL}$ ). The tube was flame-sealed and heated at $180{ }^{\circ} \mathrm{C}$ for 4 days. The reaction mixture was allowed to cool to ambient temperature overnight to afford red crystals. The tube was opened in the glove box, and the crystals were collected by filtration and characterized as $\mathbf{1 3} \cdot 2 \mathrm{C}_{7} \mathrm{H}_{8}$ 
$(0.26 \mathrm{~g}, 72 \%)$ according to analytical data. IR $\left(\mathrm{KBr}, \mathrm{cm}^{-1}\right): \tilde{v} 3345(\mathrm{~m}), 2905$ (s), 2854 (s), $2717(w), 1604(w), 1494(w), 1434(m), 1373(s), 1079(w), 1023(w), 804(w), 720(v s), 640$ (vs), 620 (vs), 590 (s), 531 (w), 487 (w), 464 (w), 418 (s). Anal. Calcd for $\mathrm{C}_{74} \mathrm{H}_{109} \mathrm{~N}_{8} \mathrm{ScTi}_{6}$ $\left(M_{\mathrm{w}}=1442.89\right):$ C 61.60, H 7.61, N 7.77. Found: C 61.02, H 7.60, N 7.71.

Synthesis of $\left[\mathbf{Y}\left(\mu_{3}-\mathbf{N}\right)_{3}\left(\mu_{3}-\mathbf{N H}\right)_{3}\left\{\mathbf{T i}_{3}\left(\eta^{5}-\mathbf{C}_{5} \mathbf{M e}_{5}\right)_{3}\left(\mu_{3}-\mathbf{N}\right)\right\}_{2}\right]$ (14). A $100 \mathrm{~mL}$ ampule (Teflon stopcock) was charged with 1 (1.00 g, $1.64 \mathrm{mmol})$, [Y $\left.\left\{\mathrm{N}\left(\mathrm{SiMe}_{3}\right)_{2}\right\}_{3}\right](0.47 \mathrm{~g}, 0.82 \mathrm{mmol})$, and toluene $(20 \mathrm{~mL})$. The reaction mixture was heated at $110^{\circ} \mathrm{C}$ without any stirring for 7 days, and the solution was allowed to cool to ambient temperature overnight to afford dark green crystals of $\mathbf{1 4} \cdot 2 \mathrm{C}_{7} \mathrm{H}_{8}(1.04 \mathrm{~g}, 85 \%)$. IR (KBr, cm $\left.{ }^{-1}\right)$ : $\tilde{v} 3336(\mathrm{w}), 2905$ (s), 2854 (s), 2718 (w), 1604 (w), 1494 (w), 1432 (s), 1373 (s), 1156 (w), 1066 (w), 1023 (w), 803 (w), 720 (vs), 694 (s), 671 (vs), 657 (vs), 636 (vs), 621 (vs), 528 (w), 464 (w), 418 (m), 400 (m). Anal. Calcd for $\mathrm{C}_{74} \mathrm{H}_{109} \mathrm{~N}_{8} \mathrm{Ti}_{6} \mathrm{Y}\left(M_{\mathrm{w}}=1486.84\right)$ : C 59.78, H 7.39, N 7.54. Found: C 59.39, H 7.04, N 7.41.

Synthesis of $\left[\mathrm{La}\left(\mu_{3}-\mathrm{N}\right)_{3}\left(\mu_{3}-\mathrm{NH}\right)_{3}\left\{\mathrm{Ti}_{3}\left(\eta^{5}-\mathrm{C}_{5} \mathrm{Me}_{5}\right)_{3}\left(\mu_{3}-\mathrm{N}\right)\right\}_{2}\right]$ (15). In a fashion similar to the preparation of 14, the treatment of $\mathbf{1}(1.00 \mathrm{~g}, 1.64 \mathrm{mmol})$ with $\left[\mathrm{La}\left\{\mathrm{N}\left(\mathrm{SiMe}_{3}\right)_{2}\right\}_{3}\right](0.51 \mathrm{~g}, 0.82$ $\mathrm{mmol})$ in toluene $(20 \mathrm{~mL})$ at $85^{\circ} \mathrm{C}$ for 7 days afforded orange crystals of $15(0.95 \mathrm{~g}, 86 \%)$. IR $\left(\mathrm{KBr}, \mathrm{cm}^{-1}\right): \tilde{v} 3326(\mathrm{w}), 2905$ (s), 2855 (s), $2719(\mathrm{w}), 1602$ (w), $1492(\mathrm{~m}), 1434$ (s), 1373 (s), 1075 (m), 1024 (m), 801 (m), 717 (vs), 691 (vs), 619 (vs), 530 (m), 468 (m), 447 (w). Anal. Calcd for $\mathrm{C}_{60} \mathrm{H}_{93} \mathrm{LaN}_{8} \mathrm{Ti}_{6}\left(M_{\mathrm{w}}=1352.56\right)$ : C 53.28, H 6.93, N 8.28. Found: C 53.90, H 6.99, N 7.79.

Synthesis of $\left[\operatorname{Sm}\left(\mu_{3}-\mathrm{N}\right)_{3}\left(\mu_{3}-\mathrm{NH}\right)_{3}\left\{\mathrm{Ti}_{3}\left(\eta^{5}-\mathrm{C}_{5} \mathrm{Me}_{5}\right)_{3}\left(\mu_{3}-\mathrm{N}\right)\right\}_{2}\right](\mathbf{1 6})$. In a fashion similar to the preparation of 14, the treatment of $1(0.30 \mathrm{~g}, 0.49 \mathrm{mmol})$ with $\left[\mathrm{Sm}\left\{\mathrm{N}\left(\mathrm{SiMe}_{3}\right)_{2}\right\}_{3}\right](0.16 \mathrm{~g}$, $0.25 \mathrm{mmol})$ in toluene $(20 \mathrm{~mL})$ at $110{ }^{\circ} \mathrm{C}$ for 2 days afforded orange crystals of $\mathbf{1 6} \cdot \mathrm{C}_{7} \mathrm{H}_{8}(0.19$ g, 53\%). IR (KBr, cm $\left.{ }^{-1}\right): \tilde{v} 3331(\mathrm{w}), 2906$ (s), 2849 (s), $1602(\mathrm{w}), 1494(\mathrm{w}), 1432(\mathrm{~m}), 1374$ (s), 1023 (w), 714 (vs), 692 (vs), 670 (vs), 620 (vs), 528 (m), 471 (m), 412 (m). Anal. Calcd 
for $\mathrm{C}_{67} \mathrm{H}_{101} \mathrm{~N}_{8} \mathrm{SmTi}_{6}\left(M_{\mathrm{w}}=1456.15\right)$ : C 55.26, H 6.99, N 7.70. Found: C 55.05, H 6.77, N 7.64 .

Synthesis of $\left[\operatorname{Eu}\left(\mu_{3}-\mathrm{N}\right)_{3}\left(\mu_{3}-\mathrm{NH}\right)_{3}\left\{\mathrm{Ti}_{3}\left(\eta^{5}-\mathrm{C}_{5} \mathrm{Me}_{5}\right)_{3}\left(\mu_{3}-\mathrm{N}\right)\right\}_{2}\right](17)$. In a fashion similar to the preparation of 14, the treatment of $\mathbf{1}(0.15 \mathrm{~g}, 0.25 \mathrm{mmol})$ with $\left[\mathrm{Eu}\left\{\mathrm{N}\left(\mathrm{SiMe}_{3}\right)_{2}\right\}_{3}\right](0.078 \mathrm{~g}$, $0.12 \mathrm{mmol})$ in toluene $(20 \mathrm{~mL})$ at $100^{\circ} \mathrm{C}$ for 4 days afforded brown crystals of $\mathbf{1 7}(0.082 \mathrm{~g}$, 51\%). IR (KBr, cm $\left.{ }^{-1}\right): \tilde{v} 3331(\mathrm{w}), 2906$ (s), $2854(\mathrm{~s}), 1494(\mathrm{w}), 1434(\mathrm{~m}), 1374(\mathrm{~s}), 1066(\mathrm{w})$, $1023(\mathrm{w}), 802(\mathrm{w}), 721(\mathrm{vs}), 693$ (vs), 654 (vs), $621(\mathrm{vs}), 584(\mathrm{~m}), 527(\mathrm{w}), 471(\mathrm{w}), 442(\mathrm{w})$, 417 (w). Anal. Calcd for $\mathrm{C}_{60} \mathrm{H}_{93} \mathrm{EuN}_{8} \mathrm{Ti}_{6}\left(M_{\mathrm{w}}=1365.62\right)$ : C 52.77, H 6.86, N 8.21. Found: C 52.75, H 6.78, N 8.44.

Synthesis of $\left[\operatorname{Er}\left(\mu_{3}-\mathrm{N}\right)_{3}\left(\mu_{3}-\mathrm{NH}\right)_{3}\left\{\operatorname{Ti}_{3}\left(\eta^{5}-\mathrm{C}_{5} \mathrm{Me}_{5}\right)_{3}\left(\mu_{3}-\mathrm{N}\right)\right\}_{2}\right]$ (18). In a fashion similar to the preparation of $\mathbf{1 3}$, the treatment of $\mathbf{1}(0.30 \mathrm{~g}, 0.49 \mathrm{mmol})$ with $\left[\mathrm{Er}\left\{\mathrm{N}\left(\mathrm{SiMe}_{3}\right)_{2}\right\}_{3}\right](0.16 \mathrm{~g}, 0.25$ mmol) in toluene $(20 \mathrm{~mL})$ at $180{ }^{\circ} \mathrm{C}$ for $24 \mathrm{~h}$ afforded $\mathbf{1 8} \cdot 2 \mathrm{C}_{7} \mathrm{H}_{8}$ as brown crystals $(0.31 \mathrm{~g}$, 79\%). IR (KBr, cm $\left.{ }^{-1}\right): \tilde{v} 3334$ (w), 2905 (s), 2855 (s), 1604 (w), 1491 (w), 1436 (m), 1373 (m), 1073 (w), 1023 (w), 941 (w), 810 (w), 722 (vs), 617 (s), 527 (m), 470 (w), 416 (s). Anal. Calcd for $\mathrm{C}_{74} \mathrm{H}_{109} \mathrm{ErN}_{8} \mathrm{Ti}_{6}\left(M_{\mathrm{w}}=1565.19\right)$ : C 56.79, H 7.02, N 7.16. Found: C 56.41, H 6.49, N 6.88.

Synthesis of $\left.\left[\mathrm{Lu}\left(\mu_{3}-\mathrm{N}\right)\right)_{3}\left(\mu_{3}-\mathrm{NH}\right)_{3}\left\{\mathrm{Ti}_{3}\left(\eta^{5}-\mathrm{C}_{5} \mathrm{Me}_{5}\right)_{3}\left(\mu_{3}-\mathrm{N}\right)\right\}_{2}\right](19)$. In a fashion similar to the preparation of 14, the treatment of $1(0.30 \mathrm{~g}, 0.49 \mathrm{mmol})$ with $\left[\mathrm{Lu}\left\{\mathrm{N}\left(\mathrm{SiMe}_{3}\right)_{2}\right\}_{3}\right](0.16 \mathrm{~g}, 0.24$ mmol) in toluene $(20 \mathrm{~mL})$ at $110^{\circ} \mathrm{C}$ for $24 \mathrm{~h}$ gave $19 \cdot \mathrm{C}_{7} \mathrm{H}_{8}$ as dark green crystals $(0.27 \mathrm{~g}$, 75\%). IR (KBr, $\left.\mathrm{cm}^{-1}\right): \tilde{v} 3339$ (w), 2905 (s), 2854 (s), 2718 (w), 1604 (w), 1493 (m), 1435 (s), $1373(\mathrm{~m}), 1067(\mathrm{~m}), 1023(\mathrm{~m}), 875(\mathrm{w}), 804(\mathrm{~m}), 721(\mathrm{~s}), 694(\mathrm{~s}), 673(\mathrm{w}), 636(\mathrm{~s}), 617(\mathrm{~s})$, $588(\mathrm{~m}), 526(\mathrm{~m}), 476(\mathrm{w}), 419(\mathrm{~s})$. Anal. Calcd for $\mathrm{C}_{67} \mathrm{H}_{101} \mathrm{LuN}_{8} \mathrm{Ti}_{6}\left(M_{\mathrm{w}}=1480.76\right)$ : C 54.35, H 6.87, N 7.57. Found: C 54.91, H 7.15, N 7.10. 
Synthesis of $\left[\left\{(\mathrm{Me} 3 \mathrm{Si})_{2} \mathrm{~N}\right\} \mathrm{Sc}\left\{\left(\mu_{3}-\mathrm{N}\right)_{2}\left(\mu_{3}-\mathrm{NH}\right) \mathrm{Ti}_{3}\left(\eta^{5}-\mathrm{C}_{5} \mathrm{Me}_{5}\right)_{3}\left(\mu_{3}-\mathrm{N}\right)\right\}\right] \quad(20) . \quad$ A $100 \mathrm{~mL}$ ampule (Teflon stopcock) was charged with $1(0.30 \mathrm{~g}, 0.49 \mathrm{mmol}),\left[\mathrm{Sc}\left\{\mathrm{N}\left(\mathrm{SiMe}_{3}\right)_{2}\right\}_{3}\right](0.26 \mathrm{~g}$, $0.49 \mathrm{mmol})$, and toluene $(30 \mathrm{~mL})$. The reaction mixture was stirred at $100{ }^{\circ} \mathrm{C}$ for 3 days to give a dark red solution. The volatile components of the solution were removed under reduced pressure, and the resultant deep red solid was vacuum-dried and characterized as $\mathbf{2 0}(0.35 \mathrm{~g}$, 88\%). IR (KBr, cm $\left.{ }^{-1}\right): \tilde{v} 3340$ (w), 2909 (vs), 2857 (s), 2722 (w), 1493 (w), 1437 (m), 1376 (s), 1244 (s), 1179 (w), 1067 (w), 1024 (m), 986 (vs), 875 (vs), 846 (vs), 832 (vs), 782 (m), 754 (w), 704 (vs), 664 (vs), 632 (vs), 619 (vs), 555 (s), 472 (w), 458 (w), 436 (m), 417 (m). ${ }^{1} \mathrm{H}$ NMR $\left(\mathrm{C}_{6} \mathrm{D}_{6}, 20{ }^{\circ} \mathrm{C}\right): \delta 11.44(\mathrm{~s}$ br., $1 \mathrm{H} ; \mathrm{NH}), 2.16\left(\mathrm{~s}, 15 \mathrm{H} ; \mathrm{C}_{5} \mathrm{Me}_{5}\right), 2.02\left(\mathrm{~s}, 30 \mathrm{H} ; \mathrm{C}_{5} \mathrm{Me}_{5}\right)$, 0.28 (s, 18H; $\left.\mathrm{SiMe}_{3}\right) .{ }^{13} \mathrm{C}\left\{{ }^{1} \mathrm{H}\right\}$ NMR $\left(\mathrm{C}_{6} \mathrm{D}_{6}, 20{ }^{\circ} \mathrm{C}\right): \delta 118.7\left(C_{5} \mathrm{Me}_{5}\right), 118.2\left(C_{5} \mathrm{Me}_{5}\right), 12.2$ $\left(\mathrm{C}_{5} M e_{5}\right), 12.1\left(\mathrm{C}_{5} M e_{5}\right), 5.2\left(\mathrm{SiMe}_{3}\right)$. Anal. Calcd for $\mathrm{C}_{36} \mathrm{H}_{64} \mathrm{~N}_{5} \mathrm{ScSi}_{2} \mathrm{Ti}_{3}\left(M_{\mathrm{w}}=811.67\right): \mathrm{C}$ 53.27, H 7.95, N 8.63. Found: C 53.05, H 8.18, N 8.24.

X-ray structure determination of $2,7,11,14,15$, and 19. Crystals of complexes 2 and 7 were obtained by slow diffusion of a tetrahydrofuran solution of $\left[\mathrm{MCl}_{3}(\text { thf })_{3}\right]$ in toluene solutions of $\mathbf{1}$. Crystals of compound $\mathbf{1 1} \cdot 0.5 \mathrm{C}_{6} \mathrm{H}_{14}$ were grown at room temperature by diffusion of hexane into a toluene solution of 11. Crystals of complexes $14 \cdot 2 \mathrm{C}_{7} \mathrm{H}_{8}, 15$ and 19. $2 \mathrm{C}_{7} \mathrm{H}_{8}$ were obtained by slow cooling of heated toluene solutions of a mixture of the reagents 1 and $\left[\mathrm{M}\left\{\mathrm{N}\left(\mathrm{SiMe}_{3}\right)_{2}\right\}_{3}\right]$ as described above. The crystals were removed from the Schlenk flasks and covered with a layer of a viscous perfluoropolyether (Fomblin ${ }^{\circledR}$ Y). A suitable crystal was selected with the aid of a microscope, attached to a glass fiber, and immediately placed in the low temperature nitrogen stream of the diffractometer. The intensity data sets were collected at $200 \mathrm{~K}$ on a Bruker-Nonius KappaCCD diffractometer equipped with an Oxford Cryostream 700 unit. Crystallographic data for all the complexes are presented in Table 1 (see page 33) 
The structures were solved, using the WINGX package, ${ }^{31}$ by direct methods (SHELXS97) and refined by least-squares against $\mathrm{F}^{2}$ (SHELXL-97). ${ }^{32}$ Crystals of 2 and $\mathbf{7}$ contained two independent molecules in the asymmetric unit, and there were no significant differences between them. All non-hydrogen atoms were anisotropically refined. All hydrogen atoms of 2 and 7 were positioned geometrically and refined using a riding model in the last cycles of refinement. DELU restraints were applied for the carbon atoms $\mathrm{C}(31)-\mathrm{C}(35)$ and $\mathrm{C}(41)-\mathrm{C}(45)$ of two pentamethylcyclopentadienyl ligands in complex 7.

Compound 11 crystallized with a half molecule of hexane. Several attempts to obtain chemically sensible models for the solvent failed, so the PLATON ${ }^{33}$ squeeze procedure was used to remove their contribution to the structure factors. All non-hydrogen atoms were anisotropically refined. All the hydrogen atoms were positioned geometrically and refined by using a riding model, except those of the imido groups $(\mathrm{H}(12), \mathrm{H}(13), \mathrm{H}(23))$, which were located in the difference Fourier map and refined isotropically.

Complexes 14 and 19 crystallized with two molecules of toluene in the Pnnm space group. Attempts to model the solvent in a sensible way also failed and similarly to 11, the PLATON $^{33}$ squeeze procedure was applied. Simultaneously, some of the carbon atoms of the pentamethylcyclopentadienyl rings linked to $\mathrm{Ti}(2)[\mathrm{C}(21), \mathrm{C}(24), \mathrm{C}(26)$ and $\mathrm{C}(29)$ for $\mathbf{1 4}$, and $C(21), C(24), C(25)$ and $C(29)$ for 19] presented disorder, and were refined in two sites with occupancy $50 \%$. However, the disorder did not affect to the location of the core of the molecule. All non-hydrogen atoms of $\mathbf{1 4}$ were anisotropically refined, except the $\mathrm{C}(21)$, $\mathrm{C}(26), \mathrm{C}(27), \mathrm{C}(28)$ and $\mathrm{C}(29)$ carbon atoms of the disordered $\mathrm{C}_{5} \mathrm{Me}_{5}$ group. Similarly to $\mathbf{1 4}$, all non-hydrogen atoms of $\mathbf{1 9}$ were anisotropically refined, except the carbon atoms $(\mathrm{C}(21)$, $\mathrm{C}(22), \mathrm{C}(23), \mathrm{C}(24), \mathrm{C}(25), \mathrm{C}(26), \mathrm{C}(28)$ and $\mathrm{C}(29))$ of the disordered $\mathrm{C}_{5} \mathrm{Me}_{5}$ ring linked to $\operatorname{Ti}(2)$. On the other hand, compound 15 crystallized as a solvent-free molecule in the $C 2 / c$ 
space group. The molecule lies on a crystallographic inversion center situated on the lanthanum atom. All non-hydrogen atoms were anisotropically refined. Finally, all hydrogen atoms of 14, 15 and 19 were included, positioned geometrically, and refined by using a riding model. The imido hydrogen atoms were statistically distributed over the six nitrogen atoms linked to the central yttrium, lanthanum or lutetium atom (final $50 \%$ of occupancy).

Pyrolysis of 14. In an argon-filled glovebox, an alumina boat was charged with a pulverized sample of compound $\mathbf{1 4} \cdot \mathrm{C}_{7} \mathrm{H}_{8}(0.20 \mathrm{~g})$. The boat was placed in the middle point of a quartz tube $(2.5 \mathrm{~cm}$ diameter $\times 40 \mathrm{~cm}$ length) equipped with two $24 / 40$ male glass joints. The tube was fitted with 24/40 vacuum adapters (Teflon stopcock), and then inserted into a horizontal tube furnace (Lindberg Blue M). The oven was heated from $20{ }^{\circ} \mathrm{C}$ to $1100{ }^{\circ} \mathrm{C}$ with a heating rate of $5{ }^{\circ} \mathrm{C} / \mathrm{min}$ under $\mathrm{Ar}\left(\mathrm{U}-\mathrm{N} 45, \mathrm{O}_{2} \leq 2 \mathrm{ppm}\right.$, and $\left.\mathrm{H}_{2} \mathrm{O} \leq 3 \mathrm{ppm}\right), \mathrm{H}_{2} / \mathrm{N}_{2}\left(6-15 \%\right.$ of $\mathrm{H}_{2}, \mathrm{O}_{2}<$ 5 ppm, and $\mathrm{H}_{2} \mathrm{O}<5$ ppm) or $\mathrm{NH}_{3}\left(\mathrm{~N} 50, \mathrm{O}_{2}<1 \mathrm{ppm}\right.$, and $\left.\mathrm{H}_{2} \mathrm{O}<1 \mathrm{ppm}\right)$ flows of 100 or 1350 $\operatorname{sccm}\left(\mathrm{cm}^{3} / \mathrm{min}\right)$. The temperature was maintained at $1100{ }^{\circ} \mathrm{C}$ for $1 \mathrm{~h}$, and the tube was allowed to cool to ambient temperature under a constant flow of the corresponding gas. The tube was taken into the glovebox and the residue was manipulated under argon atmosphere. In the pyrolysis experiment under $\mathrm{H}_{2} / \mathrm{N}_{2}$ flow, the volatile decomposition products were subsequently trapped at $-196{ }^{\circ} \mathrm{C}\left(\mathrm{N}_{2}\right.$ liquid bath) in a cooling trap, and after closing the flow of gas, benzene- $d_{6}$ was injected into the cooling flask. The resultant $\mathrm{C}_{6} \mathrm{D}_{6}$ solution was analyzed by ${ }^{1} \mathrm{H}$ NMR spectroscopy and GC-MS measurements. 


\section{Results and Discussion}

Reactions with Rare-Earth Metal Halide and Triflate Derivatives. The synthetic chemistry is outlined in Scheme 1. Treatment of $\left[\left\{\mathrm{Ti}\left(\eta^{5}-\mathrm{C}_{5} \mathrm{Me}_{5}\right)(\mu-\mathrm{NH})\right\}_{3}\left(\mu_{3}-\mathrm{N}\right)\right](\mathbf{1})$ with 1 equiv of group 3 or lanthanide trichloride tetrahydrofuran adducts $\left[\mathrm{MCl}_{3}(\mathrm{thf})_{\mathrm{n}}\right](\mathrm{M}=\mathrm{Sc}, \mathrm{Lu}, \mathrm{n}$ $=3 ; \mathrm{M}=\mathrm{Y}, \mathrm{Sm}, \mathrm{Er}, \mathrm{n}=3.5 ; \mathrm{M}=\mathrm{La}, \mathrm{n}=1.5)$ in a $4: 1$ toluene-THF mixture at room temperature afforded the precipitation of the cube-type complexes $\left[\mathrm{Cl}_{3} \mathrm{M}\left\{\left(\mu_{3}-\mathrm{NH}\right)_{3} \mathrm{Ti}_{3}\left(\eta^{5}-\right.\right.\right.$ $\left.\left.\left.\mathrm{C}_{5} \mathrm{Me}_{5}\right)_{3}\left(\mu_{3}-\mathrm{N}\right)\right\}\right](\mathrm{M}=\mathrm{Sc}(\mathbf{2}), \mathrm{Y}(\mathbf{3}), \mathrm{La}(\mathbf{4}), \mathrm{Sm}(\mathbf{5}), \mathrm{Er}(\mathbf{6}), \mathrm{Lu}(\mathbf{7}))$ as orange or yellow solids in good yields (55-83\%). Compounds 2-7 are not soluble in benzene, toluene or tetrahydrofuran but exhibit a good solubility in halogenated solvents. Complexes $\mathbf{2}, \mathbf{3}$, and 5-7 are stable in chloroform- $\mathrm{d}_{1}$ solutions at room temperature for several days according to ${ }^{1} \mathrm{H}$ NMR spectroscopy. However, the lanthanum derivative 4 in chloroform- $d_{1}$ immediately undergoes partial dissociation (ca. 15\%) to give complex $\mathbf{1}$ and presumably $\left[\mathrm{LaCl}_{3}\right]$. This mixture remains unaltered for long periods of time at room temperature.

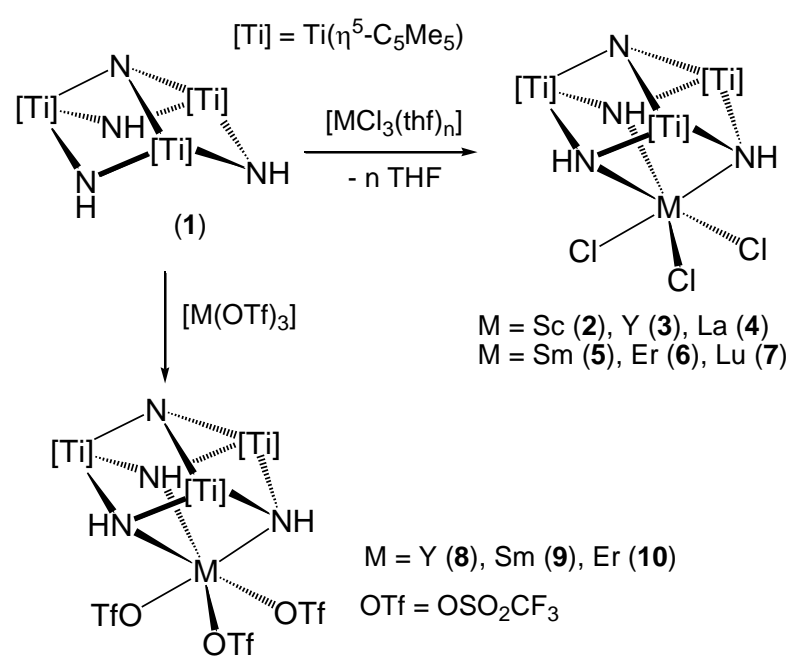

Scheme 1. Reactions of 1 with $\left[\mathrm{MCl}_{3}(\text { thf })_{\mathrm{n}}\right]$ or $\left[\mathrm{M}(\mathrm{OTf})_{3}\right]$. 
Compounds 2-7 may also be prepared by the direct reaction of 1 with one equiv of the anhydrous metal chlorides $\left[\mathrm{MCl}_{3}\right]$ in toluene or toluene-THF mixtures, but the complexes appear invariably accompanied by significant amounts of the $\left[\mathrm{MCl}_{3}\right]$ reagent according to microanalytical data. In contrast, the analogous reaction of $\mathbf{1}$ with anhydrous yttrium, samarium or erbium trifluoromethanesulfonate derivatives $\left[\mathrm{M}\left(\mathrm{O}_{3} \mathrm{SCF}_{3}\right)_{3}\right]$ in toluene afforded the precipitation of the corresponding pure triflate complexes $\left[\left(\mathrm{CF}_{3} \mathrm{SO}_{2} \mathrm{O}\right)_{3} \mathrm{M}\left\{\left(\mu_{3^{-}}\right.\right.\right.$ $\left.\left.\mathrm{NH})_{3} \mathrm{Ti}_{3}\left(\eta^{5}-\mathrm{C}_{5} \mathrm{Me}_{5}\right)_{3}\left(\mu_{3}-\mathrm{N}\right)\right\}\right](\mathrm{M}=\mathrm{Y}(\mathbf{8}), \operatorname{Sm}(\mathbf{9}), \operatorname{Er}(\mathbf{1 0}))$ (Scheme 1). Compounds 8-10 were isolated as orange solids in good yields (72-81\%) which are only soluble in halogenated solvents. The preparative reactions for compounds $\mathbf{8}$ and $\mathbf{1 0}$ were carried out in toluene or toluene-THF solutions. However, the samarium complex 9 was prepared in toluene since the presence of THF in the reaction afforded a yellow solid which is not soluble in common organic solvents. Similarly, the treatment of $\mathbf{1}$ with the lanthanum triflate derivative $\left[\mathrm{La}\left(\mathrm{O}_{3} \mathrm{SCF}_{3}\right)_{3}\right]$ in toluene-THF mixtures gave a yellow precipitate with negligible solubility. Although the C, H, N, S microanalytical data were not fully consistent for the solids isolated from several preparative reactions, the analytical results were always close to products containing metalloligand:metal triflate ratios of 1:2. Most likely the compounds contain triflate groups bridging the large samarium or lanthanum atoms as those reported in the literature for lanthanide complexes..$^{25,34}$ Interestingly, the addition of $\mathbf{1}$ (1 equiv) to a suspension of the samarium precipitate in chloroform- $d_{1}$ and subsequent heating at $70{ }^{\circ} \mathrm{C}$ overnight afforded an orange solution of complex 9 according to NMR spectroscopy.

Complexes 2-10 were characterized by spectroscopic and analytical methods, as well as by X-ray crystal structure determinations for the scandium (2), erbium (6) and lutetium (7) chloride derivatives. IR spectra $(\mathrm{KBr})$ of the chloride derivatives 2-7 show one $\mathrm{v}_{\mathrm{NH}}$ vibration, between 3331 and $3310 \mathrm{~cm}^{-1}$, whereas the IR spectra of the triflate complexes 8-10 reveal two 
$v_{\mathrm{NH}}$ vibrations, between 3329 and $3289 \mathrm{~cm}^{-1}$, in a similar range to the value determined for $\mathbf{1}$ $\left(3352 \mathrm{~cm}^{-1}\right){ }^{4}$ In addition, the infrared spectra of 8-10 show several strong absorptions between 1339 and $1010 \mathrm{~cm}^{-1}$ for the trifluoromethanesulfonate groups. ${ }^{35}$ The bands around $1338 \mathrm{~cm}^{-1}$, which are assignable to the $v_{\text {as }}\left(\mathrm{SO}_{3}\right)$ vibrations, are shifted to higher wavenumbers than that near $1270 \mathrm{~cm}^{-1}$ characteristic of the ionic $\mathrm{CF}_{3} \mathrm{SO}_{3}{ }^{-35 \mathrm{~b}}$ and are indicatives of coordinated triflate ligands. ${ }^{35 a}$ The ${ }^{1} \mathrm{H}$ and ${ }^{13} \mathrm{C}\left\{{ }^{1} \mathrm{H}\right\}$ NMR spectra in chloroform- $d_{1}$ at room temperature of the diamagnetic complexes $\mathbf{2 - 4}, \mathbf{7}$ and $\mathbf{8}$ reveal resonance signals for equivalent $\mathrm{NH}$ and $\eta^{5}-\mathrm{C}_{5} \mathrm{Me}_{5}$ groups, and agree with a $C_{3 v}$ symmetric structure in solution. The NH resonance signal in the ${ }^{1} \mathrm{H}$ NMR spectra $(\delta=13.37-12.31)$ is shifted to higher field than that found in $\mathbf{1}(\delta=13.40)$, suggesting a tridentate coordination of the metalloligand. ${ }^{18,19}$ The ${ }^{1} \mathrm{H}$ and ${ }^{13} \mathrm{C}\left\{{ }^{1} \mathrm{H}\right\}$ NMR spectra of the mildly paramagnetic samarium complexes 5 and 9 are very simple and analogous to those of the diamagnetic complexes. However, the $\mathrm{NH}$ resonance signals ( $\delta=13.55$ and 13.87, respectively) in the ${ }^{1} \mathrm{H}$ NMR spectra of $\mathbf{5}$ and 9 are shifted downfield with respect to that found in 1. All attempts to gain structural information by NMR spectroscopy of the erbium compounds $\mathbf{6}$ and $\mathbf{1 0}$ in solution failed because of their strong paramagnetism.

The isomorphous chloride complexes $\mathbf{2}, \mathbf{6},{ }^{20}$ and $\mathbf{7}$ crystallized in the space group $P 2_{1} / c$ with two independent molecules in the asymmetric unit. There are no substantial differences between the two molecules, and the structure of one of them for the scandium chloride complex 2 is shown as example in Figure 1. Selected averaged distances and angles for the two crystallographically independent molecules of complexes $\mathbf{2}, \mathbf{6}$, and $\mathbf{7}$ are compared in Table 2. The crystal structures show $\left[\mathrm{MTi}_{3} \mathrm{~N}_{4}\right]$ cube-type cores with the neutral ligand $\left[\left(\mu_{3}-\right.\right.$ $\left.\mathrm{NH})_{3} \mathrm{Ti}_{3}\left(\eta^{5}-\mathrm{C}_{5} \mathrm{Me}_{5}\right)_{3}\left(\mu_{3}-\mathrm{N}\right)\right]$ coordinating in a tripodal fashion. In all three complexes, each rare-earth center is six-coordinate and its coordination geometry is best described as distorted 
trigonal antiprismatic with one tighter triangle defined by the nitrogen atoms and with a more open one defined by the chloride ligands. This is clearly seen by comparing the N-M-N $[\mathrm{M}=$

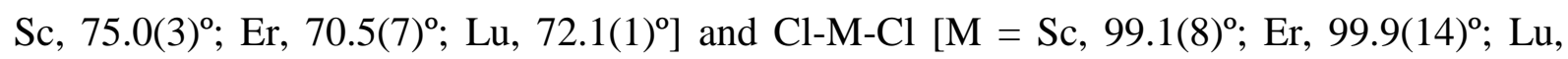
99.7(11) $)^{\circ}$ averaged angles. The coordination environment about the rare-earth atoms in complexes $\mathbf{2}, \mathbf{6}$, and 7 is analogous to those reported for trichloride complexes containing faccoordinating trinitrogen ligands such as the scandium 1,4,7-trimethyltriazacyclononane $\left[\mathrm{Sc}\left\{\mathrm{Me}_{3}[9] \mathrm{aneN}_{3}\right\} \mathrm{Cl}_{3}\right]^{24 \mathrm{a}}$ and 1,3,5-trimethyltriazacyclohexane $\left[\mathrm{Sc}\left\{\mathrm{Me}_{3}[6] \mathrm{aneN}_{3}\right\} \mathrm{Cl}_{3}\right]^{23 \mathrm{~b}}$ complexes, and the yttrium tris(pyrazolyl)silane $\left[\mathrm{Y}\left\{\mathrm{MeSi}\left(3,5-\mathrm{Me}_{2} \mathrm{pz}\right)_{3}\right\} \mathrm{Cl}_{3}\right]^{23 \mathrm{~b}}$ and tris(pyrazolyl)methane $\left[\mathrm{Y}\left\{\mathrm{HC}\left(3,5-\mathrm{Me}_{2} \mathrm{pz}\right)_{3}\right\} \mathrm{Cl}_{3}\right]^{22 \mathrm{~b}}$ derivatives. If the differences in ionic radii of $\mathrm{M}^{3+}$ in six-coordinate geometries are taken into account, ${ }^{36}$ the $\mathrm{M}-\mathrm{Cl}$ distances

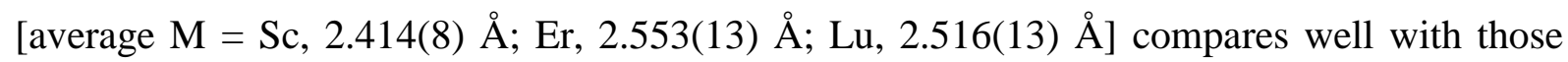
found in the above mentioned examples. However, the M-N bond lengths in 2, 6 and 7 [average M = Sc, 2.427(12) $\AA$; Er, 2.59(3) $\AA$; Lu, 2.53(2) $\AA$ ] are clearly longer than the M-N distances in those complexes (cf. average Sc-N are 2.337(8) and 2.332(1) $\AA$ in $\left[\mathrm{Sc}\left\{\mathrm{Me}_{3}[9] \mathrm{aneN}_{3}\right\} \mathrm{Cl}_{3}\right]$ and $\left[\mathrm{Sc}\left\{\mathrm{Me}_{3}[6] \mathrm{aneN}_{3}\right\} \mathrm{Cl}_{3}\right]$, respectively), suggesting a weaker coordination of the titanium tripodal ligand. This might be caused by the steric repulsion between the bulky pentamethylcyclopentadienyl ligands and the chloride groups placed in an eclipsed position. Accordingly, the distortions in bond distances and angles within the tridentate ligand are small when compared to those of $1 .^{6}$ 


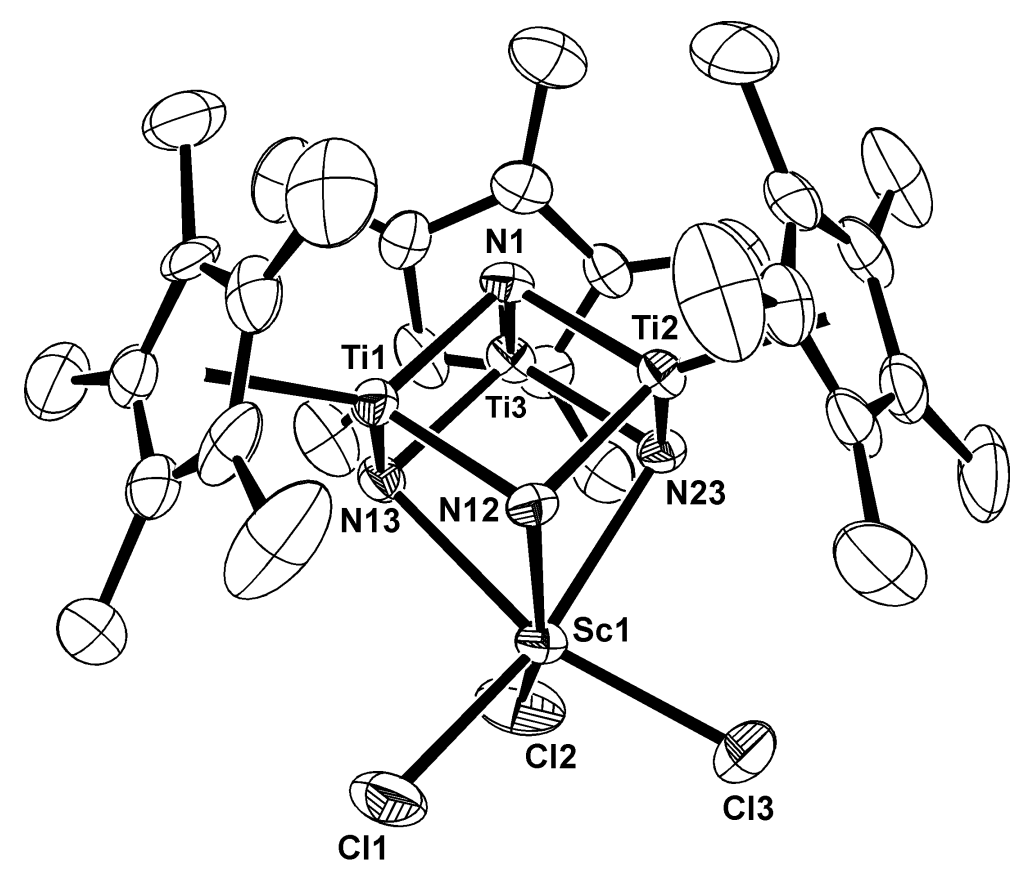

Figure 1. Perspective view with thermal ellipsoids at the $50 \%$ probability level of one of the two crystallographically independent molecules of $\mathbf{2}$. Hydrogen atoms are omitted for clarity.

Table 2. Selected Averaged Lengths $(\AA)$ and Angles (deg) for Complexes $\left[\mathrm{Cl}_{3} \mathrm{M}\left\{\left(\mu_{3}-\right.\right.\right.$ $\left.\left.\mathrm{NH})_{3} \mathrm{Ti}_{3}\left(\eta^{5}-\mathrm{C}_{5} \mathrm{Me}_{5}\right)_{3}\left(\mu_{3}-\mathrm{N}\right)\right\}\right] .^{a}$

\begin{tabular}{lccc}
\hline & $\mathrm{M}=\mathrm{Sc}(\mathbf{2})$ & $\mathrm{M}=\operatorname{Er}(\mathbf{6})$ & $\mathrm{M}=\mathrm{Lu}(\mathbf{7})$ \\
\hline $\mathrm{M}-\mathrm{N}_{\text {imido }}$ & $2.427(12)$ & $2.59(3)$ & $2.53(2)$ \\
$\mathrm{M}-\mathrm{Cl}$ & $2.414(8)$ & $2.553(13)$ & $2.516(13)$ \\
$\mathrm{Ti}-\mathrm{N}_{\text {imido }}$ & $1.974(14)$ & $1.98(2)$ & $1.978(15)$ \\
$\mathrm{Ti}-\mathrm{N}_{\text {nitrido }}$ & $1.930(7)$ & $1.931(11)$ & $1.939(8)$ \\
$\mathrm{Ti} \cdots \mathrm{Ti}$ & $2.868(9)$ & $2.869(11)$ & $2.864(6)$ \\
$\mathrm{M} \cdots \mathrm{Ti}$ & $3.219(7)$ & $3.384(11)$ & $3.328(8)$ \\
$\mathrm{N}_{\text {imido-M-N }}-\mathrm{N}$ imido & $75.0(3)$ & $70.5(7)$ & $72.1(1)$ \\
$\mathrm{Cl}-\mathrm{M}-\mathrm{Cl}$ & $99.1(8)$ & $99.9(14)$ & $99.7(11)$ \\
$\mathrm{N}_{\text {imido}}-\mathrm{Ti}-\mathrm{N}_{\text {imido }}$ & $96.9(2)$ & $98.4(7)$ & $97.7(5)$ \\
$\mathrm{N}_{\text {nitrido-Ti-N }}$ & $85.4(4)$ & $85.4(5)$ & $86.0(5)$ \\
$\mathrm{M}_{\text {imido }}$ & $93.4(4)$ & $94.7(10)$ & $94.3(4)$ \\
$\mathrm{Ti}_{\text {imido }}-\mathrm{Ti}$ & $93.2(1)$ & $93.1(7)$ & $92.8(5)$ \\
$\mathrm{Ti}_{\text {imido }}-\mathrm{Ti}$ & $95.9(4)$ & $96.0(3)$ & $95.2(5)$ \\
\hline
\end{tabular}

${ }^{a}$ Averaged values for the two independent molecules in the asymmetric unit. 
Despite several data collections, crystals of the triflate compounds 8-10 presented severe disorder precluding an accurate determination of their molecular structure by crystallographic methods. However, the treatment of yttrium (3) or lanthanum (4) chloride complexes with three equivalents of lithium 2,6-dimethylphenoxido [LiOAr] in toluene gave the analogous aryloxido derivatives $\left[(\mathrm{ArO})_{3} \mathrm{M}\left\{\left(\mu_{3}-\mathrm{NH}\right)_{3} \mathrm{Ti}_{3}\left(\eta^{5}-\mathrm{C}_{5} \mathrm{Me}_{5}\right)_{3}\left(\mu_{3}-\mathrm{N}\right)\right\}\right](\mathrm{M}=\mathrm{Y}(\mathbf{1 1}), \mathrm{La}(\mathbf{1 2}))$ (Scheme 2), and the solid-state structure of $\mathbf{1 1}$ was unambiguously determined. Compound $\mathbf{1 1}$ and 12 were isolated in good yields (95 and 82\%, respectively) as yellow solids which exhibit an enhanced solubility in benzene and toluene when compared with the triflate derivatives 810.

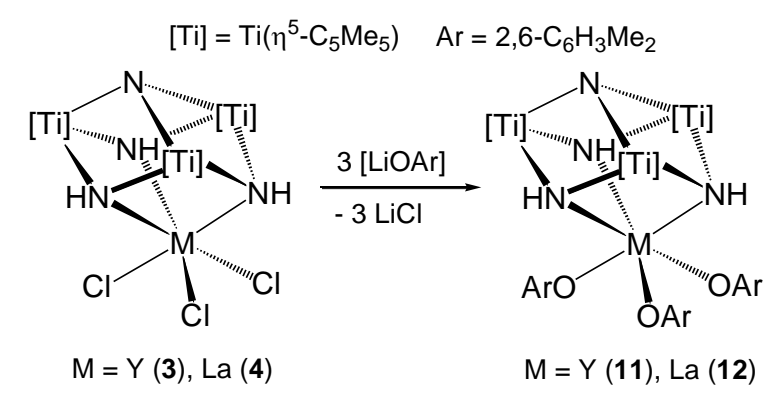

Scheme 2. Synthesis of aryloxido derivatives.

Complexes 11 and 12 were characterized by spectroscopic and analytical methods, as well as by an X-ray crystal structure determination for the yttrium derivative $\mathbf{1 1} \cdot 0.5 \mathrm{C}_{6} \mathrm{H}_{14}$. Spectroscopic data of $\mathbf{1 1}$ and $\mathbf{1 2}$ are similar to those of complexes 2-10. ${ }^{1} \mathrm{H}$ and ${ }^{13} \mathrm{C}\left\{{ }^{1} \mathrm{H}\right\} \mathrm{NMR}$ spectra in chloroform- $d_{1}$ at room temperature show resonances for equivalent $\mathrm{NH}$ and $\eta^{5}$ $\mathrm{C}_{5} \mathrm{Me}_{5}$ groups, and are consistent with a $C_{3 v}$ symmetry in solution. In addition, the spectra reveal resonance signals for three equivalent 2,6-dimethylphenoxido ligands coordinated to the yttrium or lanthanum centers. 
The X-ray crystal structure of $\mathbf{1 1}$ is presented in Figure 2, and selected distances and angles are given in Table 3 . The molecular structure shows a distorted $\left[\mathrm{YTi}_{3} \mathrm{~N}_{4}\right]$ cube-type core similar to those of the chloride complexes $\mathbf{2 , 6}$ and 7. Yttrium is bonded to three oxygen atoms of the aryloxido ligands and three imido groups of the $\left[\mathrm{Ti}_{3}(\mu-\mathrm{NH})_{3}\left(\mu_{3}-\mathrm{N}\right)\right]$ fragment. The Y-O distances (average 2.110(1) $\AA$ ) are in the range typical of terminal yttrium 2,6dimethylphenoxidos, ${ }^{37}$ and compare well with the $\mathrm{M}-\mathrm{O}$ bond lengths determined in the crystal structures of complexes $\left[\mathrm{M}\left\{\mathrm{HC}\left(3,5-\mathrm{Me}_{2} \mathrm{pz}\right)_{3}\right\}(\mathrm{OAr})_{3}\right]$ [average $\mathrm{M}=\mathrm{Sc},{ }^{23 \mathrm{~b}} 1.962(2) \AA ; \mathrm{M}=$ $\left.\mathrm{Nd},{ }^{22 \mathrm{~b}} 2.207(5) \AA ; \mathrm{M}=\mathrm{Sm},{ }^{22 \mathrm{~b}} 2.180(3) \AA\right]$ after correction of the difference in ionic radii. ${ }^{36}$ However, the Y-N bond lengths in 11 (2.618(2)-2.662(2) $\AA$ ) are longer than expected from the $\mathrm{M}-\mathrm{N}$ distances found in those complexes $\left[\mathrm{M}\left\{\mathrm{HC}\left(3,5-\mathrm{Me}_{2} \mathrm{pz}\right)_{3}\right\}(\mathrm{OAr})_{3}\right](\mathrm{M}=\mathrm{Sc}, 2.354(2)$ $\AA ; \quad M=N d, 2.599(5) \AA ; M=S m, 2.565(5) \AA)$. This might be caused by the steric repulsion between the bulky pentamethylcyclopentadienyl ligands and the 2,6-dimethylphenoxido groups. The minimization of this repulsion might also explain the coordination geometry about the yttrium atom in $\mathbf{1 1}$, which is best described as intermediate between trigonal prismatic and antiprismatic. This is clearly seen when one looks perpendicularly down onto the triangle defined by the nitrogen atoms and that defined by the oxygen atoms, and finds that the average twist angle $\phi$, measured in the plane of projection, between those triangular faces is $32(1)^{\circ}$ (Figure 2). ${ }^{38}$ For comparison, the analogous twist angle $\phi$ in the chloride complexes 2, 6, and 7 spans 34(3)-54(2) ${ }^{\circ}$, and therefore the coordination geometry about the rare-earth center in those complexes is somewhat closer to trigonal antiprismatic $\left(\phi=60^{\circ}\right)$. 


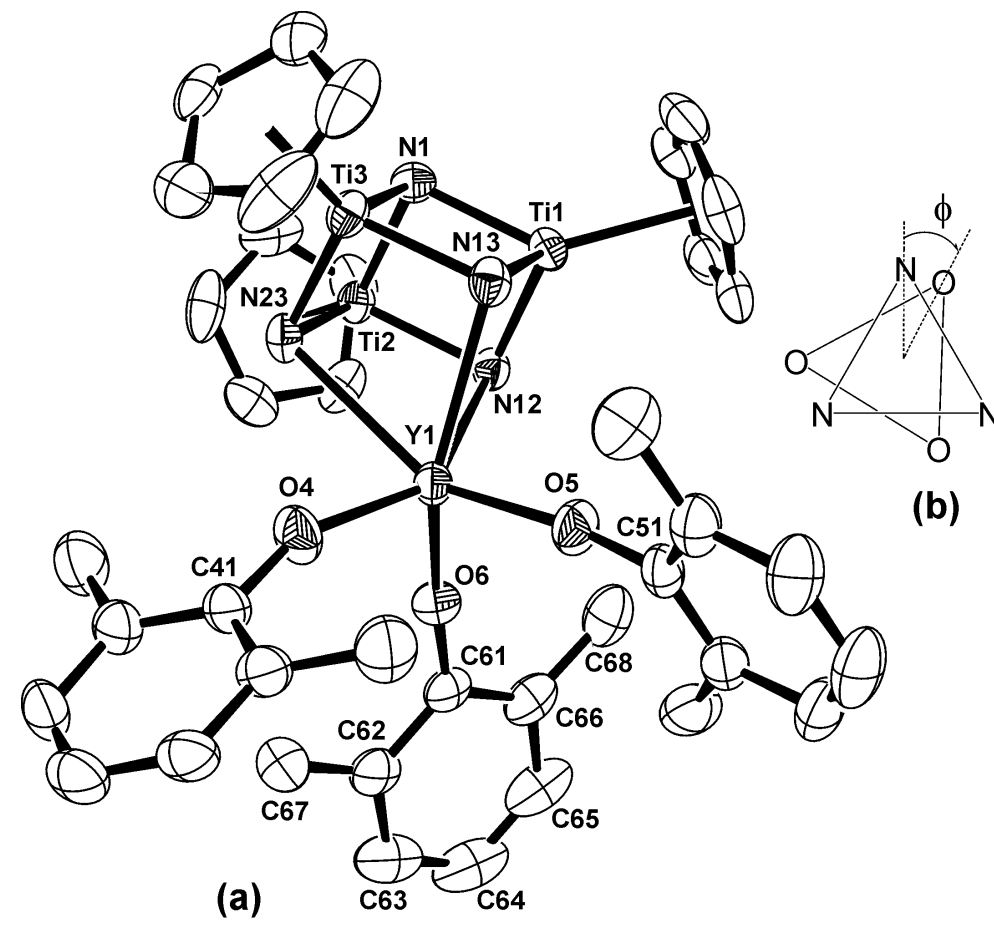

Figure 2. (a) Perspective view of $\mathbf{1 1}$ with thermal ellipsoids at the $50 \%$ probability level. Methyl groups of the pentamethylcyclopentadienyl ligands and hydrogen atoms are omitted for clarity. (b) Schematic representation of the six-coordinate geometry about the yttrium center in $\mathbf{1 1}$.

Table 3. Selected Lengths ( $\mathrm{A})$ and Angles (deg) for 11 .

\begin{tabular}{|c|c|c|c|}
\hline $\mathrm{Y}(1)-\mathrm{N}(12)$ & $2.629(2)$ & $\mathrm{Y}(1)-\mathrm{O}(4)$ & $2.109(2)$ \\
\hline $\mathrm{Y}(1)-\mathrm{N}(13)$ & $2.618(2)$ & $\mathrm{Y}(1)-\mathrm{O}(5)$ & $2.109(2)$ \\
\hline $\mathrm{Y}(1)-\mathrm{N}(23)$ & $2.662(2)$ & $\mathrm{Y}(1)-\mathrm{O}(6)$ & $2.111(2)$ \\
\hline Ti-N $\mathrm{N}_{\text {imido }}$ (av) & $1.943(10)$ & Ti-N(1) (av) & $1.912(1)$ \\
\hline $\mathrm{Ti} \cdots \mathrm{Ti}(\mathrm{av})$ & $2.823(4)$ & $\mathrm{Ti} \cdots \mathrm{Y}(1)(\mathrm{av})$ & $3.427(15)$ \\
\hline $\mathrm{N}(12)-\mathrm{Y}(1)-\mathrm{N}(13)$ & $68.1(1)$ & $\mathrm{O}(4)-\mathrm{Y}(1)-\mathrm{O}(5)$ & $102.4(1)$ \\
\hline $\mathrm{N}(13)-\mathrm{Y}(1)-\mathrm{N}(23)$ & $67.8(1)$ & $\mathrm{O}(4)-\mathrm{Y}(1)-\mathrm{O}(6)$ & $102.9(1)$ \\
\hline $\mathrm{N}(12)-\mathrm{Y}(1)-\mathrm{N}(23)$ & $67.9(1)$ & $\mathrm{O}(5)-\mathrm{Y}(1)-\mathrm{O}(6)$ & $101.2(1)$ \\
\hline $\mathrm{Y}(1)-\mathrm{O}(4)-\mathrm{C}(41)$ & $157.3(2)$ & $\mathrm{Y}(1)-\mathrm{O}(5)-\mathrm{C}(51)$ & $171.9(2)$ \\
\hline $\mathrm{Y}(1)-\mathrm{O}(6)-\mathrm{C}(61)$ & $165.4(2)$ & $\mathrm{N}_{\text {imido }}-\mathrm{Ti}-\mathrm{N}_{\text {imido }}$ (av) & $98.5(3)$ \\
\hline $\mathrm{N}_{\text {imido }}-\mathrm{Ti}-\mathrm{N}(1)$ (av) & $85.8(3)$ & Ti-N imido $-\mathrm{Ti}$ (av) & $93.2(1)$ \\
\hline Ti-N imido $\mathrm{Y}(1)(\mathrm{av})$ & $95.7(6)$ & Ti-N(1)-Ti (av) & $95.1(2)$ \\
\hline
\end{tabular}


Reactions with Rare-Earth Metal Amido Derivatives. The synthetic chemistry is outlined in Scheme 3. Treatment of $\mathbf{1}$ with group 3 or lanthanide bis(trimethylsilyl)amido derivatives $\left[\mathrm{M}\left\{\mathrm{N}\left(\mathrm{SiMe}_{3}\right)_{2}\right\}_{3}\right]$ in toluene at $85-180{ }^{\circ} \mathrm{C}$ afforded the corner-shared double-cube nitrido complexes $\left[\mathrm{M}\left(\mu_{3}-\mathrm{N}\right)_{3}\left(\mu_{3}-\mathrm{NH}\right)_{3}\left\{\mathrm{Ti}_{3}\left(\eta^{5}-\mathrm{C}_{5} \mathrm{Me}_{5}\right)_{3}\left(\mu_{3}-\mathrm{N}\right)\right\}_{2}\right](\mathrm{M}=\mathrm{Sc}(\mathbf{1 3}), \mathrm{Y}(\mathbf{1 4}), \mathrm{La}$ (15), Sm (16), Eu (17), Er (18), Lu (19)) in good yields (51-86\%). Compound 14 was also prepared by the reaction of $\mathbf{1}$ with one equiv of the yttrium alkyl derivative $\left[\mathrm{Y}\left(\mathrm{CH}_{2} \mathrm{SiMe}_{3}\right)_{3}(\mathrm{thf})_{3}\right]$. Whereas the reaction of $\mathbf{1}$ with the triamido reagent $\left[\mathrm{Y}\left\{\mathrm{N}\left(\mathrm{SiMe}_{3}\right)_{2}\right\}_{3}\right]$ is very slow at room temperature, complex $\mathbf{1}$ reacted almost immediately with the yttrium trialkyl derivative. The reactions in benzene- $d_{6}$ were monitored by NMR spectroscopy but no soluble intermediates were detected, and the final spectra revealed only resonances assigned to free bis(trimethylsilyl)amine or tetramethylsilane.

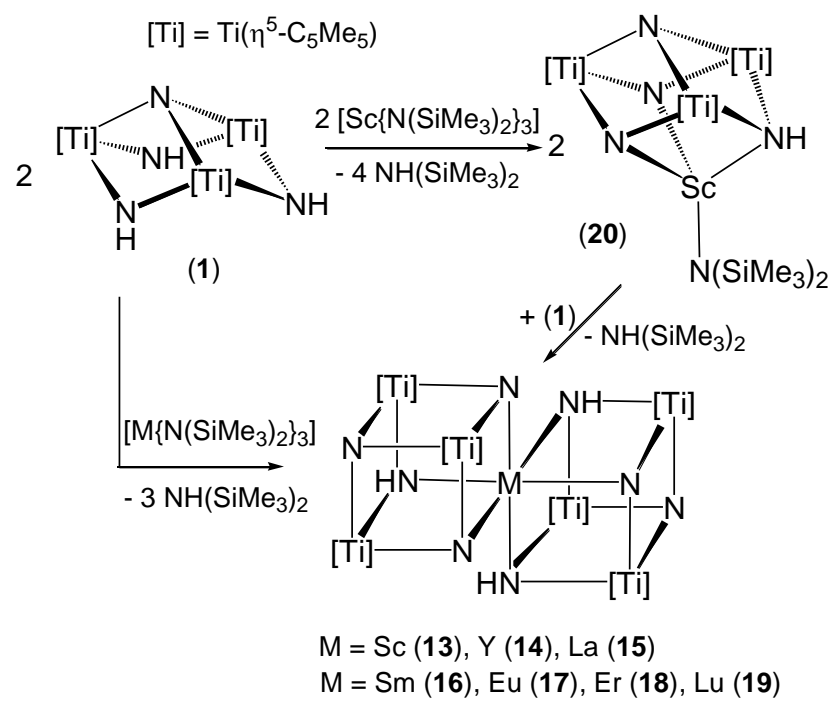

Scheme 3. Reactions of 1 with $\left[\mathrm{M}\left\{\mathrm{N}\left(\mathrm{SiMe}_{3}\right)_{2}\right\}_{3}\right]$.

Complexes 13-19 are not soluble in common organic solvents, and their lack of volatility precludes their characterization by mass spectrometry (EI, $70 \mathrm{eV}$ ). Therefore, the compounds were characterized by IR spectroscopy and C, H, N microanalysis, as well as by 
X-ray crystal structure determinations for $\mathbf{1 4}, \mathbf{1 5}$, and 19. Crystals of 13-19 contain two (13, $14,18,19)$, one $(16)$ or zero $(15,17)$ toluene molecules per double-cube unit according to crystallographic or analytical data. However, once the crystals are separated from the solution, the toluene solvent molecules are gradually lost within hours at room temperature. The molecular structures of $\mathbf{1 5}$ and $\mathbf{1 9}$ are presented in Figures 3 and 4, while selected distances and angles of complexes 14, 15, and 19 are compared in Table 4. The structures confirm the expected corner-shared double-cube $\left[\mathrm{MTi}_{6} \mathrm{~N}_{8}\right]$ cores similar to those found in our previous studies with transition ${ }^{18 b}$ or main-group ${ }^{39}$ metals. The six-coordinate geometry about the yttrium, lanthanum, or lutetium centers is best described as trigonal antiprismatic, whereby the two tridentate organometallic ligands adopt a mutually staggered disposition. The coordination environment about the rare-earth centers resembles those determined for hydrotris(pyrazolyl)borate lanthanide(II) complexes $\left[\operatorname{Ln}\left\{\mathrm{HB}\left(3,5-\mathrm{Me}_{2} \mathrm{pz}\right)_{3}\right\}_{2}\right]^{40}$ and the lanthanide(III) compounds $\left[\operatorname{Ln}\left\{\mathrm{HB}\left(3,5-\mathrm{Me}_{2} \mathrm{pz}\right)_{3}\right\}_{2}\right] \mathrm{X} .{ }^{41}$ Within the tridentate ligands, the titanium-nitrogen bond lengths and the titanium-nitrogen-titanium angles in complexes $\mathbf{1 4}$, $\mathbf{1 5}$, and $\mathbf{1 9}$ are very similar and compare well with those determined for $\mathbf{1}^{6}$ 


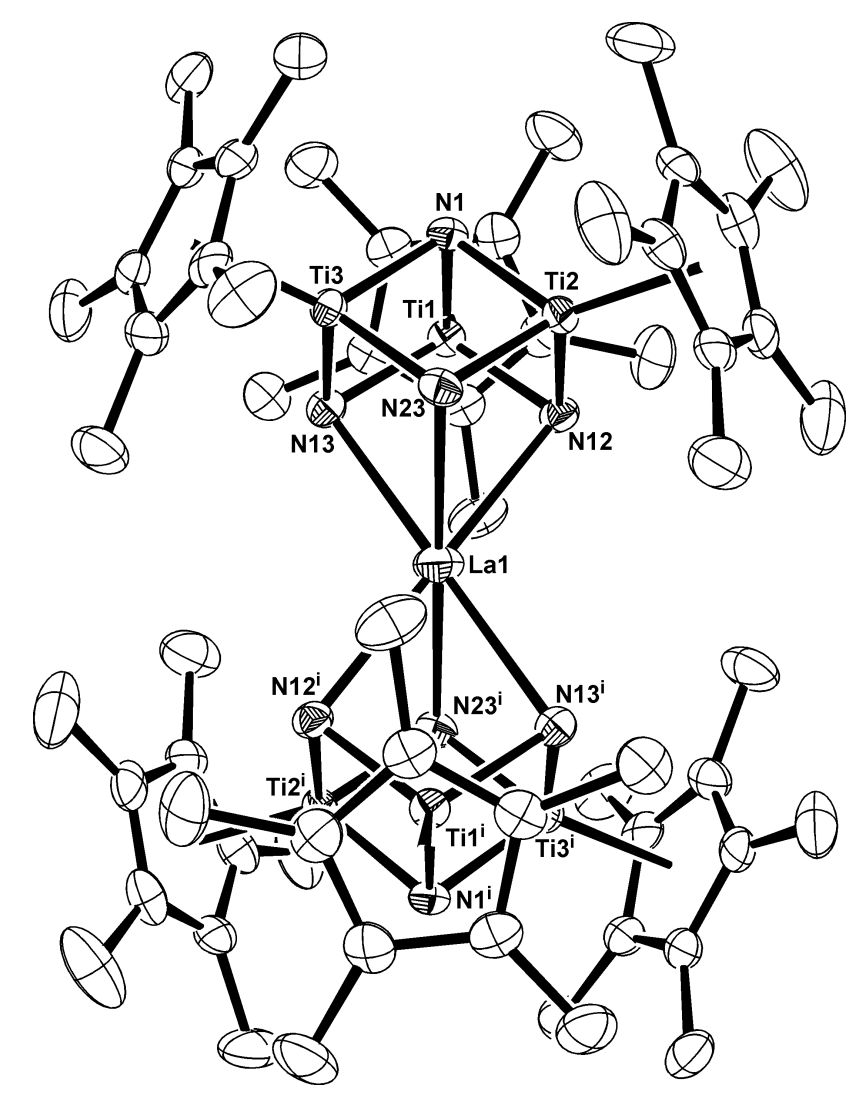

Figure 3. Perspective view of $\mathbf{1 5}$ with thermal ellipsoids at the $50 \%$ probability level. Hydrogen atoms are omitted for clarity. Symmetry code: (i) $1 / 2-x, 1 / 2-y,-z$. 


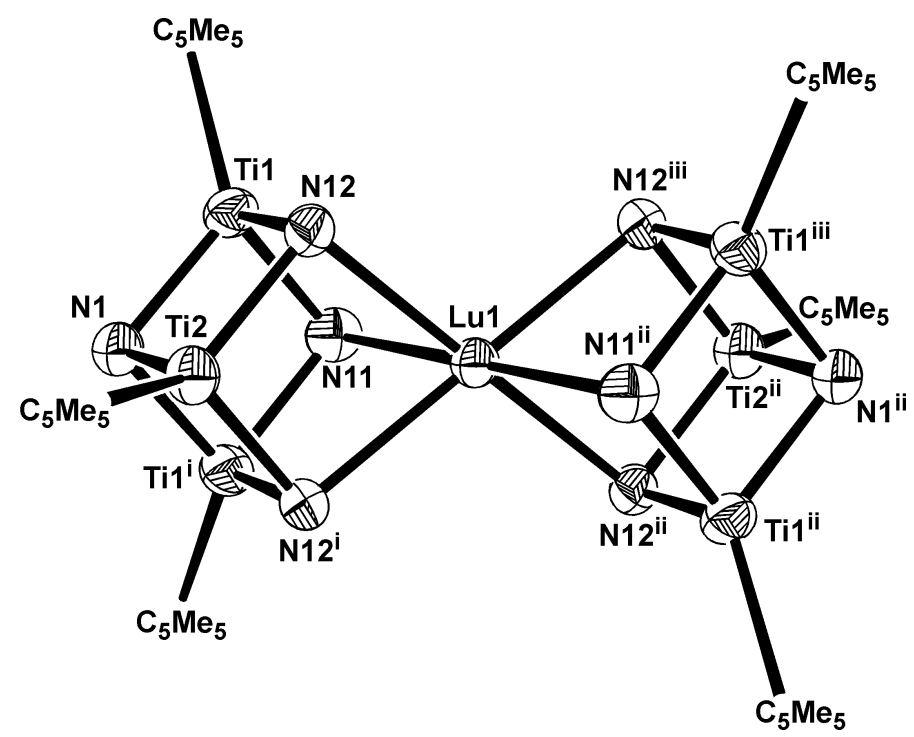

Figure 4. Simplified view of $\mathbf{1 9}$ with thermal ellipsoids at the 50\% probability level.

Pentamethylcyclopentadienyl rings and hydrogen atoms are omitted for clarity. Symmetry code: (i) $x, y,-z$; (ii) $2-x,-y,-z$; (iii) $2-x,-y, z$.

Table 4. Selected Averaged Lengths (A) and Angles (deg) for Complexes 14, 15, and 19.

\begin{tabular}{lccc}
\hline & $\mathrm{M}=\mathrm{Y}(\mathbf{1 4})$ & $\mathrm{M}=\mathrm{La}(\mathbf{1 5})$ & $\mathrm{M}=\mathrm{Lu}(\mathbf{1 9})$ \\
\hline $\mathrm{M}-\mathrm{N}$ & $2.439(4)$ & $2.601(11)$ & $2.381(15)$ \\
$\mathrm{Ti}-\mathrm{N}$ & $1.952(9)$ & $1.947(9)$ & $1.960(10)$ \\
$\mathrm{M} \cdots \mathrm{Ti}$ & $3.251(5)$ & $3.417(9)$ & $3.200(4)$ \\
$\mathrm{Ti} \cdots \mathrm{Ti}$ & $2.821(2)$ & $2.806(8)$ & $2.825(1)$ \\
$\mathrm{Ti}-\mathrm{N}-\mathrm{Ti}$ & $92.5(4)$ & $92.2(3)$ & $92.4(7)$ \\
$\mathrm{N}(1)-\mathrm{Ti}-\mathrm{N}$ & $87.4(2)$ & $87.7(2)$ & $87.6(2)$ \\
$\mathrm{N}-\mathrm{Ti}-\mathrm{N}$ & $96.0(2)$ & $97.2(1)$ & $95.2(6)$ \\
$\mathrm{N}-\mathrm{M}-\mathrm{N}^{a}$ & $73.1(1)$ & $68.4(1)$ & $75.1(1)$ \\
& $106.9(1)$ & $111.6(1)$ & $104.9(1)$ \\
Ti-N-M & $94.8(2)$ & $96.3(5)$ & $94.3(4)$ \\
${ }^{a}$ Narrower values correspond to intracube and wider values to intercube N-M-N angles.
\end{tabular}

Complexes 14-19 were invariably obtained by treatment of 1 with 0.5 or 1 equiv of the triamido reagents $\left[\mathrm{M}\left\{\mathrm{N}\left(\mathrm{SiMe}_{3}\right)_{2}\right\}_{3}\right]$ at different temperatures, but the reaction of 1 with one equiv of $\left[\mathrm{Sc}\left\{\mathrm{N}\left(\mathrm{SiMe}_{3}\right)_{2}\right\}_{3}\right]$ in toluene at $100^{\circ} \mathrm{C}$ afforded the monoamido scandium derivative $\left[\left\{\left(\mathrm{Me}_{3} \mathrm{Si}\right)_{2} \mathrm{~N}\right\} \operatorname{Sc}\left\{\left(\mu_{3}-\mathrm{N}\right)_{2}\left(\mu_{3}-\mathrm{NH}\right) \mathrm{Ti}_{3}\left(\eta^{5}-\mathrm{C}_{5} \mathrm{Me}_{5}\right)_{3}\left(\mu_{3}-\mathrm{N}\right)\right\}\right]$ (20) (Scheme 3). Complex 20 is 
stable at high temperatures in benzene- $d_{6}$ solution according to NMR spectroscopy. However, upon addition of one equiv of $\mathbf{1}$ to this solution and subsequent heating at $180{ }^{\circ} \mathrm{C}$ the spectra showed resonances assigned to $\mathrm{NH}\left(\mathrm{SiMe}_{3}\right)_{2}$ along with a red precipitate characterized as compound 13 .

Complex 20 was obtained in $88 \%$ yield as a red solid, which is very soluble in toluene and hexane, and was characterized by spectroscopic and analytical methods. The ${ }^{1} \mathrm{H}$ NMR spectrum in benzene- $d_{6}$ at room temperature reveals two resonances for $\eta^{5}-\mathrm{C}_{5} \mathrm{Me}_{5}$ ligands in a 1:2 ratio, a singlet for one $\mathrm{N}\left(\mathrm{SiMe}_{3}\right)_{2}$ group and a broad signal for the $\mathrm{NH}$ imido ligand. These NMR data are consistent with a $C_{s^{-}}$-symmetric structure in solution as those reported for the monoamido $^{39 b}$ or monoalkyl ${ }^{19 c}$ aluminum(III) derivatives $\left[\operatorname{RAl}\left\{\left(\mu_{3}-\mathrm{N}\right)_{2}\left(\mu_{3}-\mathrm{NH}\right) \mathrm{Ti}_{3}\left(\eta^{5}-\right.\right.\right.$ $\left.\left.\left.\mathrm{C}_{5} \mathrm{Me}_{5}\right)_{3}\left(\mu_{3}-\mathrm{N}\right)\right\}\right]\left(\mathrm{R}=\mathrm{N}\left(\mathrm{SiMe}_{3}\right)_{2}, \mathrm{Me}, \mathrm{CH}_{2} \mathrm{SiMe}_{3}\right)$.

Thermal Decomposition of Heterometallic Double-Cube Nitrido Complexes. The thermal stabilities in the solid-state of complexes $\left[\mathrm{M}\left(\mu_{3}-\mathrm{N}\right)_{3}\left(\mu_{3}-\mathrm{NH}\right)_{3}\left\{\mathrm{Ti}_{3}\left(\eta^{5}-\mathrm{C}_{5} \mathrm{Me}_{5}\right)_{3}\left(\mu_{3}-\right.\right.\right.$ $\left.\mathrm{N})\}_{2}\right](\mathrm{M}=\mathrm{Y}(\mathbf{1 4}), \mathrm{La}(\mathbf{1 5}), \mathrm{Er}(\mathbf{1 8}))$ were examined as representative examples of the large number of corner-shared double-cube nitrido derivatives reported by our laboratory. ${ }^{18 b, 39}$ This type of compounds was chosen because they are not volatile as determined by mass spectrometry (EI, $70 \mathrm{eV}$ ) and sublimation experiments under vacuum conditions. Therefore, any mass loss in the decomposition would be due to thermal degradation of the complexes.

Initially, the decomposition behavior of crystalline samples of compounds $14 \cdot \mathrm{C}_{7} \mathrm{H}_{8}, \mathbf{1 5}$ and 18. $\mathrm{C}_{7} \mathrm{H}_{8}$ under an argon flow was investigated by simultaneous thermogravimetric analysis (TGA) and differential thermal analysis (DTA) experiments. The volatile components generated in the degradation of the complexes were analyzed by coupled mass spectrometry (MS). The TGA and DTA curves for the yttrium derivative $\mathbf{1 4} \cdot \mathrm{C}_{7} \mathrm{H}_{8}$ are shown 
in Figure 5 (Figures S3 and S4 in the Supporting Information show the TGA/DTA curves for 15 and $18 \cdot \mathrm{C}_{7} \mathrm{H}_{8}$ ). The TGA curves for $14 \cdot \mathrm{C}_{7} \mathrm{H}_{8}$ and $\mathbf{1 8} \cdot \mathrm{C}_{7} \mathrm{H}_{8}$ display a weight loss of $\approx 7$ and $6 \%$ respectively, between 120 and $190{ }^{\circ} \mathrm{C}$ (endothermic peaks at 159 and $140{ }^{\circ} \mathrm{C}$ in the DTA curves, respectively), which cannot be observed during the decomposition of the lanthanum complex 15. These mass losses at the very beginning of the decomposition are due to release of toluene solvent molecules of crystallization, which are absent in $\mathbf{1 5}$. The elimination of toluene was unambiguously established by MS $(\mathrm{m} / \mathrm{z}, 92)$ while the theoretical mass loss for one toluene molecule from compounds $\mathbf{1 4} \cdot \mathrm{C}_{7} \mathrm{H}_{8}$ and $\mathbf{1 8} \cdot \mathrm{C}_{7} \mathrm{H}_{8}$ is 6.6 and $6.3 \%$, respectively. The main mass loss (20-23\%) for the three complexes starts at about $200{ }^{\circ} \mathrm{C}$ and is finished around $600{ }^{\circ} \mathrm{C}$ (endothermic peaks at $514-522{ }^{\circ} \mathrm{C}$ in the DTA curves). Analysis of the volatile components generated in this step by MS revealed fragments derived of the $\mathrm{C}_{5} \mathrm{Me}_{5}$ groups $\left(\mathrm{m} / \mathrm{z}, 135\left[\mathrm{C}_{5} \mathrm{Me}_{5}\right]^{+}, 119\left[\mathrm{C}_{5} \mathrm{Me}_{3} \mathrm{CH}_{2}\right]^{+}, 16\left[\mathrm{CH}_{4}\right]^{+}, 15\left[\mathrm{CH}_{3}\right]^{+}\right)$. Between 600 and $1000{ }^{\circ} \mathrm{C}$ the TGA curves show additional mass losses of about $3 \%$ to give black residues containing 67,73 or $70 \%$ of the initial mass of compounds $14 \cdot \mathrm{C}_{7} \mathrm{H}_{8}, \mathbf{1 5}$ and $\mathbf{1 8} \cdot \mathrm{C}_{7} \mathrm{H}_{8}$, respectively. These results suggest that a considerable amount of carbon arising from the $\mathrm{C}_{5} \mathrm{Me}_{5}$ groups should be present in the residues, which were found amorphous by powder X-ray diffraction. Elemental analysis of the black solid obtained in the TGA of $\mathbf{1 4}$ demonstrated those high levels of carbon (41.9\%) along with lower levels of hydrogen and nitrogen $(0.7$ and 5.1\%, respectively). 


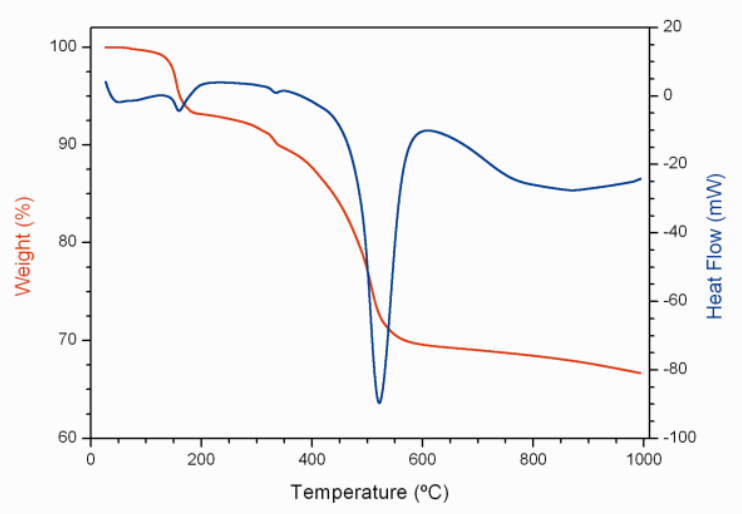

Figure 5. TGA (red) and DTA (blue) curves for the degradation of $\mathbf{1 4} \cdot \mathrm{C}_{7} \mathrm{H}_{8}$ under Ar flow at a heating rate of $10{ }^{\circ} \mathrm{C} / \mathrm{min}$.

The pyrolysis of the yttrium compound $\mathbf{1 4} \cdot \mathrm{C}_{7} \mathrm{H}_{8}$ under different atmospheres was investigated $\left(\mathrm{Ar}, \mathrm{H}_{2} / \mathrm{N}_{2}, \mathrm{NH}_{3}\right)$ in more detail. Heating under an argon flow $(100 \mathrm{sccm})$ from 20 to $1100{ }^{\circ} \mathrm{C}$ gave rise to a black powder (63\% of the initial mass), which was found to contain high levels of carbon (48.8\%) by elemental analysis (Table 5). Compositional analysis by energy dispersive analysis of X-rays (EDX) shows the presence of titanium and yttrium in the solid (see the Supporting Information). The ceramic yield and large amounts of carbon derived of the $\mathrm{C}_{5} \mathrm{Me}_{5}$ groups in the resultant product are consistent with those obtained in the TGA experiment under argon for this compound.

Table 5. Ceramic Yields and Characteristics of the Pyrolyzed Products of $14 \cdot \mathrm{C}_{7} \mathrm{H}_{8}$.

\begin{tabular}{|c|c|c|c|c|c|c|}
\hline \multirow{2}{*}{ Experiment } & \multirow{2}{*}{ Color } & \multirow{2}{*}{$\begin{array}{l}\text { Ceramic } \\
\text { Yield }(\%)\end{array}$} & \multicolumn{4}{|c|}{ Elemental analysis $(\%)^{a}$} \\
\hline & & & $\mathrm{C}$ & $\mathrm{H}$ & $\mathrm{N}$ & $\mathrm{O}$ \\
\hline Ar flow ${ }^{b}$ & black & 63 & 48.8 & 0.3 & 5.1 & 3.9 \\
\hline $\mathrm{H}_{2} / \mathrm{N}_{2}$ flow $^{b}$ & black & 58 & 42.7 & 0.5 & 9.4 & 4.0 \\
\hline $\mathrm{NH}_{3}$ flow $^{b}$ & $\begin{array}{l}\text { iridescent } \\
\text { garnet }\end{array}$ & 55 & 22.9 & 0.4 & 13.2 & 1.5 \\
\hline $\mathrm{NH}_{3}$ flow $^{c}$ & $\begin{array}{l}\text { iridescent } \\
\text { garnet }\end{array}$ & 32 & 0.2 & 0.3 & 18.0 & 0.2 \\
\hline
\end{tabular}


The pyrolysis of $\mathbf{1 4} \cdot \mathrm{C}_{7} \mathrm{H}_{8}$ from room temperature to $1100{ }^{\circ} \mathrm{C}$ was also carried out under a flow $(100 \mathrm{sccm})$ of $\mathrm{H}_{2} / \mathrm{N}_{2}\left(6-15 \% \mathrm{H}_{2}\right)$ to give a black residue with $58 \%$ of the initial mass. Elemental analysis of this solid reveals about $42.7 \%$ of carbon and $9.4 \%$ of nitrogen, whereas the EDX measurement shows the presence of titanium and yttrium. The volatile by-products of the decomposition were trapped at $-196^{\circ} \mathrm{C}$ (liquid nitrogen bath), and after closing the flow of gas, benzene- $d_{6}$ was injected into the cooling trap. The resulting $\mathrm{C}_{6} \mathrm{D}_{6}$ solution was analyzed by ${ }^{1} \mathrm{H}$ NMR spectroscopy and GC-MS measurements, and $\mathrm{C}_{5} \mathrm{Me}_{5} \mathrm{H}$ was unambiguously identified in both techniques. It appears that the potentially reactive $\mathrm{H}_{2} / \mathrm{N}_{2}$ atmosphere somewhat facilitates the elimination of the organic groups, but the ceramic yield and carbon content of the residue are still very high.

Finally, pyrolyses of $\mathbf{1 4} \cdot \mathrm{C}_{7} \mathrm{H}_{8}$ from 20 to $1100{ }^{\circ} \mathrm{C}$ were performed under different flows of anhydrous ammonia. While the decomposition of $\mathbf{1 4}$ under a flow of $\mathrm{NH}_{3}$ of $100 \mathrm{sccm}$ gave an iridescent garnet solid with $55 \%$ of the initial mass, a higher flow of $\mathrm{NH}_{3}(1350 \mathrm{sccm})$ afforded a residue mass of $32 \%$, which is closer to the calculated mass for complete degradation to "YTi $6 \mathrm{~N}_{8}$ " (35\%) or "YTi $6 \mathrm{~N}_{7}$ " (34\%). Accordingly, the residue obtained in the former experiment still contains high levels of carbon (22.9\% by elemental analysis) and low levels of nitrogen (13.2\%), while the solid isolated under a large flow of ammonia has only a very small amount of carbon $(0.2 \%)$ along with a nitrogen content $(18.0 \%)$ closer to the expected values for $\mathrm{YTi}_{6} \mathrm{~N}_{8}$ or $\mathrm{YTi}_{6} \mathrm{~N}_{7}$ compositions (23.0 and $20.7 \%$, respectively).

The garnet solid obtained under a large flow of $\mathrm{NH}_{3}$ was studied in more detail. Elemental analyses reveal very low hydrogen and oxygen levels ( 0.3 and $0.2 \%$, respectively), whereas compositional analysis by EDX confirms the presence of titanium and yttrium in the solid. Powder X-ray diffraction analysis showed that the residue was essentially amorphous, and only weak peaks could be assigned to $\mathrm{TiN}$ and $\mathrm{Y}_{2} \mathrm{O}_{3}$. Rare-earth nitrides exhibit a high 
reactivity toward air to give the metal oxides, ${ }^{42}$ and minor oxidation/hydrolysis of the sample might explain the $\mathrm{Y}_{2} \mathrm{O}_{3}$ detection in the XRD experiment. Indeed, the elemental analysis of a sample exposed to air for $20 \mathrm{~h}$ at room temperature gave an increased oxygen content $(1.3 \%)$ without any significant variation on the $\mathrm{C}, \mathrm{H}$ and $\mathrm{N}$ levels $(0.4,0.0$ and $18.3 \%$, respectively).

The ceramic yield and the negligible carbon content in this residue agree with an efficient removal of the $\mathrm{C}_{5} \mathrm{Me}_{5}$ groups in the precursor, probably via acid-base reactions with $\mathrm{NH}_{3}$. We are currently investigating the pyrolysis under $\mathrm{NH}_{3}$ at different conditions (e.g., lower temperatures and slower heating rates) of compound $\mathbf{1 4}$ and other cube-type heterometallic nitrido complexes in order to optimize the preparation and characterization of metal nitride materials.

\section{Conclusion}

We have presented the systematic syntheses of a series of well-characterized titaniumgroup 3/lanthanide molecular nitrides by reaction of the imido-nitrido titanium complex $\mathbf{1}$ with several derivatives of the rare-earth metals. Complex $\mathbf{1}$ is capable of acting as a neutral facially coordinating ligand to metal halide, triflate or aryloxido derivatives to give singlecube complexes $\left[\mathrm{X}_{3} \mathrm{M}\left\{\left(\mu_{3}-\mathrm{NH}\right)_{3} \mathrm{Ti}_{3}\left(\eta^{5}-\mathrm{C}_{5} \mathrm{Me}_{5}\right)_{3}\left(\mu_{3}-\mathrm{N}\right)\right\}\right]$. Analogous treatment with metal triamido reagents produces the deprotonation of $\mathbf{1}$ to yield corner-shared double-cube nitrido derivatives $\left[\mathrm{M}\left(\mu_{3}-\mathrm{N}\right)_{3}\left(\mu_{3}-\mathrm{NH}\right)_{3}\left\{\mathrm{Ti}_{3}\left(\eta^{5}-\mathrm{C}_{5} \mathrm{Me}_{5}\right)_{3}\left(\mu_{3}-\mathrm{N}\right)\right\}_{2}\right]$ and the corresponding amine molecules. Thermal decomposition experiments (TGA/DTA and pyrolysis) carried out on selected double-cube compounds under argon atmosphere give black residues containing large amounts of carbon due to inefficient removal of the pentamethylcyclopentadienyl ligands. However, the pyrolysis of the yttrium double-cube derivative $\mathbf{1 4}$ at $1100{ }^{\circ} \mathrm{C}$ under $\mathrm{NH}_{3}$ leads to the formation of a metal nitride material with a negligible carbon level. 
Acknowledgment. We thank Dr. Rosa Rojas of the ICMM for assistance with the TGA/DTA experiments. We are also grateful to the Spanish MEC (CTQ2008-00061/BQU), Comunidad de Madrid and the Universidad de Alcalá (CCG10-UAH/PPQ-5935), and the Factoría de Cristalización (CONSOLIDER-INGENIO 2010 CSD2006-00015) for financial support of this research. J.C. thanks the MEC for a doctoral fellowship.

Supporting Information Available: Perspective views of the molecular structure of complexes 7 and 14, TGA/TDA curves for complexes 15 and 18, TGA-MS spectra, EDX spectra of solids obtained in the thermal decomposition of 14, and PXRD spectrum of the solid obtained in the pyrolysis of $\mathbf{1 4}$ under a large flow of $\mathrm{NH}_{3}$ (PDF). X-ray crystallographic files in CIF format for complexes $\mathbf{2}, \mathbf{7}, \mathbf{1 1}, \mathbf{1 4}, \mathbf{1 5}$, and $\mathbf{1 9}$. This material is available free of charge via the Internet at http://pubs.acs.org. 
Table 1. Experimental Data for the X-ray Diffraction Studies on 2, 7, 11, 14, 15, and 19.

\begin{tabular}{|c|c|c|c|c|c|c|}
\hline & 2 & 7 & 11. $0.5 \mathrm{C}_{6} \mathrm{H}_{14}$ & $\mathbf{1 4} \cdot 2 \mathrm{C}_{7} \mathrm{H}_{8}$ & 15 & 19. $2 \mathrm{C}_{7} \mathrm{H}_{8}$ \\
\hline Formula & $\mathrm{C}_{30} \mathrm{H}_{48} \mathrm{Cl}_{3} \mathrm{~N}_{4} \mathrm{ScTi}_{3}$ & $\mathrm{C}_{30} \mathrm{H}_{48} \mathrm{Cl}_{3} \mathrm{LuN}_{4} \mathrm{Ti}_{3}$ & $\mathrm{C}_{57} \mathrm{H}_{82} \mathrm{~N}_{4} \mathrm{O}_{3} \mathrm{Ti}_{3} \mathrm{Y}$ & $\mathrm{C}_{74} \mathrm{H}_{109} \mathrm{~N}_{8} \mathrm{Ti}_{6} \mathrm{Y}$ & $\mathrm{C}_{60} \mathrm{H}_{93} \mathrm{LaN}_{8} \mathrm{Ti}_{6}$ & $\mathrm{C}_{74} \mathrm{H}_{109} \mathrm{LuN}_{8} \mathrm{Ti}_{6}$ \\
\hline$M_{\mathrm{r}}$ & 759.73 & 889.74 & 1103.88 & 1487.00 & 1352.73 & 1573.06 \\
\hline$T[\mathrm{~K}]$ & $200(2)$ & $200(2)$ & $200(2)$ & $200(2)$ & $200(2)$ & $200(2)$ \\
\hline$\lambda[\AA]$ & 0.71073 & 0.71073 & 0.71073 & 0.71073 & 0.71073 & 0.71073 \\
\hline crystal system & Monoclinic & Monoclinic & Monoclinic & Orthorhombic & Monoclinic & Orthorhombic \\
\hline space group & $P 2_{1} / c$ & $P 2_{1} / c$ & $P 2_{1} / c$ & Pnnm & $C 2 / c$ & Pnnm \\
\hline$a[\AA] ; \alpha\left[^{\circ}\right]$ & $11.175(3)$ & $11.118(3)$ & $12.443(2)$ & 14.717(1); & $27.961(6)$ & 14.654(1); \\
\hline$b[\AA] ; \beta\left[^{\circ}\right]$ & $17.723(3) ; 94.17(4)$ & $17.895(3) ; 94.20(2)$ & $21.245(2) ; 110.97(2)$ & 15.433(5); & $11.588(1) ; 106.13(2)$ & 15.439(4); \\
\hline$c[\AA] ; \gamma\left[{ }^{\circ}\right]$ & $37.034(11)$ & $37.373(5)$ & $23.112(6)$ & 16.701(5); & $20.911(5)$ & 16.711(4); \\
\hline$V\left[\AA^{3}\right]$ & $7315(3)$ & $7416(3)$ & $5705(2)$ & $3793(2)$ & $6509(2)$ & $3781(1)$ \\
\hline $\mathrm{Z}$ & 8 & 8 & 4 & 2 & 4 & 2 \\
\hline$\rho_{\text {calcd }}\left[\mathrm{g} \mathrm{cm}^{-3}\right]$ & 1.380 & 1.594 & 1.285 & 1.302 & 1.380 & 1.382 \\
\hline$\mu \mathrm{MoK} \alpha\left[\mathrm{mm}^{-1}\right]$ & 1.053 & 3.503 & 1.456 & 1.399 & 1.381 & 1.938 \\
\hline$F(000)$ & 3152 & 3552 & 2324 & 1560 & 2792 & 1624 \\
\hline $\begin{array}{l}\text { crystal size } \\
{\left[\mathrm{mm}^{3}\right]}\end{array}$ & $0.21 \times 0.14 \times 0.11$ & $0.18 \times 0.13 \times 0.11$ & $0.32 \times 0.26 \times 0.16$ & $0.29 \times 0.22 \times 0.14$ & $0.31 \times 0.19 \times 0.13$ & $0.33 \times 0.18 \times 0.16$ \\
\hline$\theta$ range $(\mathrm{deg})$ & 3.01 to 27.51 & 3.17 to 25.02 & 3.00 to 27.50 & 5.07 to 25.24 & 5.04 to 27.51 & 3.22 to 27.53 \\
\hline index ranges & $\begin{array}{l}-14 \text { to } 14, \\
-23 \text { to } 23, \\
0 \text { to } 48\end{array}$ & $\begin{array}{l}-13 \text { to } 13, \\
-21 \text { to } 21 \text {, } \\
0 \text { to } 44\end{array}$ & $\begin{array}{l}-16 \text { to } 15 \\
-27 \text { to } 27 \\
-30 \text { to } 15\end{array}$ & $\begin{array}{l}-17 \text { to } 17 \\
-18 \text { to } 18, \\
0 \text { to } 20\end{array}$ & $\begin{array}{l}-36 \text { to } 34 \\
-15 \text { to } 15 \\
0 \text { to } 27\end{array}$ & $\begin{array}{l}-19 \text { to } 19 \\
-20 \text { to } 20, \\
0 \text { to } 21\end{array}$ \\
\hline $\begin{array}{l}\text { Reflections } \\
\text { collected }\end{array}$ & 123787 & 129009 & 121012 & 59932 & 67603 & 44357 \\
\hline Unique data & $16798[\mathrm{R}(\mathrm{int})=0.105]$ & $13041[\mathrm{R}(\mathrm{int})=0.094]$ & $13088[\mathrm{R}(\mathrm{int})=0.033]$ & $3530[\mathrm{R}(\mathrm{int})=0.075]$ & $7396[\mathrm{R}$ (int) $=0.059]$ & $4487[\mathrm{R}(\mathrm{int})=0.100]$ \\
\hline $\begin{array}{l}\text { obsd data } \\
{[\mathrm{I}>2 \sigma(\mathrm{I})]}\end{array}$ & 8559 & 7829 & 9286 & 2847 & 4911 & 2988 \\
\hline $\begin{array}{l}\text { Goodness-of-fit } \\
\text { on } \mathrm{F}^{2}\end{array}$ & 1.004 & 1.032 & 1.096 & 1.115 & 1.046 & 1.046 \\
\hline $\begin{array}{l}\text { final } R^{a} \text { indices } \\
{[\mathrm{I}>2 \sigma(\mathrm{I})]}\end{array}$ & $\begin{array}{l}\mathrm{R} 1=0.074, \\
\mathrm{wR} 2=0.165\end{array}$ & $\begin{array}{l}\mathrm{R} 1=0.069 \\
\mathrm{wR} 2=0.163\end{array}$ & $\begin{array}{l}\mathrm{R} 1=0.041 \\
\mathrm{wR} 2=0.106\end{array}$ & $\begin{array}{l}\mathrm{R} 1=0.096 \\
\mathrm{wR} 2=0.237\end{array}$ & $\begin{array}{l}\mathrm{R} 1=0.056, \\
\mathrm{wR} 2=0.125\end{array}$ & $\begin{array}{l}\mathrm{R} 1=0.074, \\
\mathrm{wR} 2=0.193\end{array}$ \\
\hline $\begin{array}{l}R^{a} \text { indices (all } \\
\text { data) }\end{array}$ & $\begin{array}{l}\mathrm{R} 1=0.162 \\
\mathrm{wR} 2=0.206\end{array}$ & $\begin{array}{l}\mathrm{R} 1=0.125 \\
\mathrm{wR} 2=0.194\end{array}$ & $\begin{array}{l}\mathrm{R} 1=0.070 \\
\mathrm{wR} 2=0.117\end{array}$ & $\begin{array}{l}\mathrm{R} 1=0.118 \\
\mathrm{wR} 2=0.251\end{array}$ & $\begin{array}{l}\mathrm{R} 1=0.100, \\
\mathrm{wR} 2=0.142\end{array}$ & $\begin{array}{l}\mathrm{R} 1=0.113, \\
\mathrm{wR} 2=0.213\end{array}$ \\
\hline $\begin{array}{l}\text { largest diff. } \\
\left.\text { peak/hole[e. } \AA^{-3}\right]\end{array}$ & 1.076 and -1.042 & 1.707 and -2.007 & 0.463 and -0.460 & 1.141 and -0.577 & 1.027 and -0.571 & 1.428 and -1.444 \\
\hline
\end{tabular}

${ }^{a} R I=\Sigma|| F_{0}|-| F_{c} \| /\left[\Sigma\left|F_{0}\right|\right] \quad w R 2=\left\{\left[\Sigma w\left(F_{0}^{2}-F_{c}^{2}\right)^{2}\right] /\left[\Sigma w\left(F_{0}^{2}\right)^{2}\right]\right\}^{1 / 2}$ 


\section{References}

(1) (a) Dehnicke, K.; Strähle, J. Angew. Chem. Int. Ed. Engl. 1981, 20, 413-426. (b) Dehnicke, K.; Strähle, J. Angew. Chem. Int. Ed. Engl. 1992, 31, 955-978. (c) Dehnicke, K.; Weller, F.; Strähle, J. Chem. Soc. Rev. 2001, 30, 125-135.

(2) (a) Nugent, W. A.; Mayer, J. M. Metal-Ligand Multiple Bonds; Wiley: New York, 1988.

(b) Eikey, R. A.; Abu-Omar, M. M. Coord. Chem. Rev. 2003, 243, 83-124.

(3) For selected examples of dinuclear early transition-metal nitrido derivatives, see: (a) Haddad, T. S.; Aistars, A.; Ziller, J. W.; Doherthy, N. M. Organometallics 1993, 12, 24202422. (b) Berno, P.; Gambarotta, S. Angew. Chem. Int. Ed. Engl. 1995, 34, 822-824. (c) Song, J.-I., Gambarotta, S. Chem. Eur. J. 1996, 2, 1258-1263. (d) Tayebani, M.; Feghali, K.; Gambarotta, S.; Bensimon, C. Organometallics 1997, 16, 5084-5088. (e) Clentsmith, G. K. B.; Bates, V. M. E.; Hitchcock, P. B.; Cloke, F. G. N. J. Am. Chem. Soc. 1999, 121, 10444-10445. (f) Gauch, E.; Hoppe, H.; Strähle, J. J. Organomet. Chem. 2000, 593, 175179. (g) Carmalt, C. J.; Mileham, J. D.; White, A. J. P.; Williams, D. J. New. J. Chem. 2000, 24, 929-930. (h) Hirotsu, M.; Fontaine, P. P.; Epshteyn, A.; Zavalij, P.; Sita, L. R. J. Am. Chem. Soc. 2007, 129, 9284-9285. (i) Akagi, F.; Matsuo, T.; Kawaguchi, H. Angew. Chem. Int. Ed. 2007, 46, 8778-8781. (j) Nikiforov, G. B.; Vidyaratne, I.; Gambarotta, S.; Korobkov, I. Angew. Chem. Int. Ed. 2009, 48, 7415-7419.

(4) Abarca, A.; Gómez-Sal, P.; Martín, A.; Mena, M.; Poblet, J.-M.; Yélamos, C. Inorg. Chem. 2000, 39, 642-651.

(5) (a) Plenio, H.; Roesky, H. W.; Noltemeyer, M. Angew. Chem. Int. Ed. Engl. 1988, 27, 1330-1331. (b) Banaszak Holl, M. M.; Kersting, M.; Pendley, B. D.; Wolczanski, P. T. Inorg. Chem. 1990, 29, 1518-1526. (c) Duan, Z.; Verkade, J. G. Inorg. Chem. 1996, 35, 
5325-5327. (d) Mindiola, D. J.; Meyer, K.; Cherry, J.-P. F.; Baker, T. A.; Cummins, C. C. Organometallics 2000, 19, 1622-1624.

(6) Roesky, H. W.; Bai, Y.; Noltemeyer, M. Angew. Chem. Int. Ed. Engl. 1989, 28, 754-755.

(7) (a) Gómez-Sal, P.; Martín, A.; Mena, M.; Yélamos, C. J. Chem. Soc., Chem. Commun. 1995, 2185-2186. (b) Abernethy, C. D.; Bottomley, F.; Decken, A.; Cameron, T. S. Organometallics 1996, 15, 1758-1759. (c) Fickes, M.; Odom, A. L.; Cummins, C. C. Chem. Commun. 1997, 1993-1994.

(8) (a) Banaszak Holl, M. M.; Wolczanski, P. T.; Van Duyne, G. D. J. Am. Chem. Soc. 1990, 112, 7989-7994. (b) Banaszak Holl, M. M.; Wolczanski, P. T. J. Am. Chem. Soc. 1992, 114, 3854-3858. (c) Bai, G.; Müller, P.; Roesky, H. W.; Usón, I. Organometallics 2000, 19, 4675-4677. (d) Bai, G.; Roesky, H. W.; Müller, P. Bull. Pol. Acad. Sci-Chem. 2002, 50, 110.

(9) Bai, G.; Roesky, H. W.; Noltemeyer, M.; Hao, H.; Schmidt, H-G. Organometallics 2000, $19,2823-2825$.

(10) (a) Lee, S. C.; Holm, R. H. Proc. Natl. Acad. Sci. U.S.A. 2003, 100, 3595-3600. (b) Lee, S. C.; Holm, R. H. Chem. Rev. 2004, 104, 1135-1157.

(11) (a) Kuganathan, N.; Green, J. C.; Himmel, H.-J. New J. Chem. 2006, 30, 1253-1262. (b) Himmel, H.-J.; Reiher, M. Angew. Chem. Int. Ed. 2006, 45, 6264-6288.

(12) (a) Gambarotta, S.; Scott, J. Angew. Chem. Int. Ed. 2004, 43, 5298-5308. (b) Spencer, L. P.; MacKay, B. A.; Patrick, B. O.; Fryzuk, M. D. Proc. Natl. Acad. Sci. U.S.A. 2006, 103, 17094-17098. (c) Fryzuk, M. D. Acc. Chem. Res. 2009, 42, 127-133.

(13) Oyama, S. T. Ed. The Chemistry of Transition Metal Carbides and Nitrides; Blackie Academic \& Professional: London, 1996. 
(14) Banaszak Holl, M. M.; Wolczanski, P. T.; Proserpio, D.; Bielecki, A.; Zax, D. B. Chem. Mater. 1996, 8, 2468-2480.

(15) (a) Kniep, R. Pure Appl. Chem. 1997, 69, 185-191. (b) Niewa, R.; DiSalvo, F. J. Chem. Mater. 1998, 10, 2733-2752. (c) Gregory, D. H. J. Chem. Soc., Dalton Trans. 1999, 259270. (d) Gregory, D. H. Coord. Chem. Rev. 2001, 215, 301-345.

(16) (a) Polarz, S.; Orlov, A.; Hoffmann, A.; Wagner, M. R.; Rauch, C.; Kirste, R.; Gehlhoff, W.; Aksu, Y.; Driess, M.; van der Berg, M. W. E.; Lehmann, M. Chem. Mater. 2009, 21, 3889-3897. (b) Heitz, S.; Epping, J.-D.; Aksu, Y.; Driess, M. Chem. Mater. 2010, 22, 45634571. (c) Heitz, S.; Aksu, Y.; Merschjann, C.; Driess, M. Chem. Eur. J. 2011, 17, 39043910, and references therein.

(17) (a) Elder, S. H.; Doerrer, L. H.; DiSalvo, F. J.; Parise, J. B.; Guyomard, D.; Tarascon, J. M. Chem. Mater. 1992, 4, 928-937. (b) Paine, R. T.; Janik, J. F.; Fan, M. Polyhedron 1994, 13, 1225-1232. (c) Cheng, F.; Sugahara, Y.; Kuroda, K. Appl. Organomet. Chem. 2001, 15, 710-716. (d) Fan, M.; Duesler, E. N.; Janik, J. F.; Paine, R. T. J. Inorg. Organomet. Polym. Mater. 2007, 17, 423-437.

(18) (a) Freitag, K.; Gracia, J.; Martín, A.; Mena, M.; Poblet, J.-M.; Sarasa, J. P.; Yélamos, C. Chem. Eur. J. 2001, 7, 3644-3651. (b) Abarca, A.; Galakhov, M.; Gracia, J.; Martín, A.; Mena, M.; Poblet, J.-M.; Sarasa, J. P.; Yélamos, C. Chem. Eur. J. 2003, 9, 2337-2346. (c) Martín, A.; Martínez-Espada, N.; Mena, M.; Pérez-Redondo, A.; Yélamos, C. Inorg. Chem. 2006, 45, 6901-6911. (d) Martínez-Espada, N.; Mena, M.; Mosquera, M. E. G.; PérezRedondo, A.; Yélamos, C. Organometallics 2010, 29, 6732-6738.

(19) (a) García-Castro, M.; Martín, A.; Mena, M.; Yélamos, C. Organometallics 2004, 23, 1496-1500. (b) García-Castro, M.; Gracia, J.; Martín, A.; Mena, M.; Poblet, J.-M.; Sarasa, 
J. P.; Yélamos, C. Chem. Eur. J. 2005, 11, 1030-1041. (c) García-Castro, M.; Martín, A.; Mena, M.; Yélamos, C. Organometallics 2007, 26, 408-416.

(20) Caballo, J.; García-Castro, M.; Martín, A.; Mena, M.; Pérez-Redondo, A.; Yélamos, C. Inorg. Chem. 2008, 47, 7077-7079.

(21) (a) Santos, I.; Marques, N. New J. Chem. 1995, 19, 551-571. (b) Marques, N.; Sella, A.; Takats, J. Chem. Rev. 2002, 102, 2137-2159.

(22) (a) Bigmore, H. R.; Lawrence, S. C.; Mountford, P.; Tredget, C. S. Dalton Trans. 2005, 635-651. (b) Sella, A.; Brown, S. E.; Steed, J. W.; Tocher, D. A. Inorg. Chem. 2007, 46, $1856-1864$.

(23) (a) Lawrence S. C.; Ward, B. D.; Dubberley, S. R.; Kozak, C. M.; Mountford, P. Chem. Commun. 2003, 2880-2881. (b) Tredget, C. S.; Lawrence, S. C.; Ward, B. D.; Howe, R. G.; Cowley, A. R.; Mountford, P. Organometallics 2005, 24, 3136-3148.

(24) (a) Hajela, S.; Schaefer, W. P.; Bercaw, J. E. J. Organomet. Chem. 1997, 532, 45-53. (b) Bambirra, S.; van Leusen, D.; Meetsma, A.; Hessen, B.; Teuben, J. H. Chem. Commun. 2001, 637-638. (c) Bambirra, S.; Meetsma, A.; Hessen, B. Acta Crystallogr. 2006, E62, m314-m316. (d) Bambirra, S.; Meetsma, A.; Hessen, B.; Bruins, A. P. Organometallics 2006, 25, 3486-3495. (e) Bambirra, S.; van Leusen, D.; Tazelaar, C. G. J.; Meetsma, A.; Hessen, B. Organometallics 2007, 26, 1014-1023.

(25) Köhn, R. D.; Pan, Z.; Kociok-Köhn, G.; Mahon, M. F. J. Chem. Soc., Dalton Trans. 2002, 2344-2347.

(26) (a) Edelmann, F. T. Lanthanides and Actinides, in Herrmann/Brauer, Synthetic Methods of Organometallic and Inorganic Chemistry; Herrmann, W. A., Ed.; Georg Thieme Verlag: 
New York, 1996, Vol. 6. (b) Willey, G. R.; Woodman, T. J.; Drew, M. G. B. Polyhedron 1997, 16, 3385-3393, and references therein.

(27) Wu, S. H.; Ding, Z.-B.; Li, X.-J. Polyhedron 1994, 13, 2679-2681.

(28) Lappert, M. F.; Pearce, R. J. Chem. Soc., Chem. Commun. 1973, 126-126.

(29) Alyea, E. C.; Bradley, D. C.; Copperthwaite, R. G. J. Chem. Soc., Dalton Trans. 1972, $1580-1584$.

(30) (a) Bradley, D. C.; Ghotra, J. S.; Hart, F. A. J. Chem. Soc., Chem. Comm. 1972, 349-350.

(b) Bradley, D. C.; Ghotra, J. S.; Hart, F. A. J. Chem. Soc., Dalton Trans. 1973, 1021-1023.

(31) Farrugia, L. J. J. Appl. Crystallogr. 1999, 32, 837-838.

(32) Sheldrick, G. M. Acta Crystallogr. 2008, A64, 112-122.

(33) Spek, A. L. J. Appl. Crystallogr. 2003, 36, 7-13.

(34) (a) Mashima, K.; Oshiki, T.; Tani, K. J. Org. Chem. 1998, 63, 7114-7116. (b) Hitchcock, P. B.; Hulkes, A. G.; Lappert, M. F.; Protchenko, A. V. Inorg. Chim. Acta 2006, 359, 29983006 , and references therein.

(35) (a) Lawrance, G. A. Chem. Rev. 1986, 86, 17-33. (b) Johnston, D. H.; Shriver, D. F. Inorg. Chem. 1993, 32, 1045-1047. (c) Huang, W.; Frech, R.; Wheeler, R. A. J. Phys. Chem. 1994, $98,100-110$.

(36) Shannon, R. D. Acta Crystallogr. 1976, A32, 751-767.

(37) (a) Evans, W. J.; Olofson, J. M.; Ziller, J. W. Inorg. Chem. 1989, 28, 4308-4309. (b) Evans, W. J.; Ansari, M. A.; Ziller, J. W.; Khan, S. I. J. Organomet. Chem. 1998, 553, 141-148.

(38) (a) Cotton, F. A.; Wilkinson, G.; Murillo, C.; Bochmann, M. Advanced Inorganic Chemistry, $6^{\text {th }}$ ed; John Wiley \& Sons: New York, 1999, pp 6-7. (b) Fleischer, E. B.; 
Gebala, A. E.; Swift, D. R.; Tasker, P. A. Inorg. Chem. 1972, 11, 2775-2784. (c) El-Kurdi, S.; Seppelt, K. Chem. Eur. J. 2011, 17, 3956-3962.

(39) (a) Martín, A.; Mena, M.; Pérez-Redondo, A.; Yélamos, C. Inorg. Chem. 2004, 43, 24912498. (b) García-Castro, M.; Martín, A.; Mena, M.; Yélamos, C. Chem. Eur. J. 2009, 15, $7180-7191$.

(40) (a) Takats, J.; Zhang, X. W.; Day, V. W.; Eberspacher, T. A. Organometallics 1993, 12, 4286-4288. (b) Maunder, G. H.; Sella, A.; Tocher, D. A. J. Chem. Soc., Chem. Commun. 1994, $885-886$.

(41) (a) Liu, S.-Y.; Maunder, G. H.; Sella, A.; Stevenson, M.; Tocher, D. A. Inorg. Chem. 1996, 35, 76-81. (b) Hillier, A. C.; Zhang, X. W.; Maunder, G. H.; Liu, S. Y.; Eberspacher, T. A.; Metz, M. V.; McDonald, R.; Domingos, A.; Marques, N.; Day, V. W.; Sella, A.; Takats, J. Inorg. Chem. 2001, 40, 5106-5116. (c) Han, F.; Zhang, J.; Yi, W.; Zhang, Z.; Yu, J.; Weng, L.; Zhou, X. Inorg. Chem. 2010, 49, 2793-2798.

(42) (a) LaDuca, R. L.; Wolczanski, P. T. Inorg. Chem. 1992, 31, 1311-1313. (b) Fitzmaurice, J. C.; Hector, A.; Rowley, A. T.; Parkin, I. P. Polyhedron 1994, 13, 235-240. (c) Thiede, T. B.; Krasnopolski, M.; Milanov, A. P.; de los Arcos, T.; Ney, A.; Becker, H.-W.; Rogalla, D.; Winter, J.; Devi, A.; Fischer, R. A. Chem. Mater. 2011, 23, 1430-1440. 